Research

\title{
Gene expression profiling of potential peroxisome proliferator-activated receptor (PPAR) target genes in human hepatoblastoma cell lines inducibly expressing different PPAR isoforms
}

Keisuke Tachibana ${ }^{1}$, Yumi Kobayashi ${ }^{1}$, Toshiya Tanaka ${ }^{2}$, Masayuki Tagami ${ }^{1}$, Akira Sugiyama ${ }^{2,3}$, Tatsuya Katayama ${ }^{1}$, Chihiro Ueda1 ${ }^{1}$, Daisuke Yamasaki ${ }^{1}$, Kenji Ishimoto1, Mikako Sumitomo1, Yasutoshi Uchiyama ${ }^{2,3}$, Takahide Kohro², Juro Sakai², Takao Hamakubo², Tatsuhiko Kodama² and Takefumi Doi*1,4

Address: ${ }^{1}$ Graduate School of Pharmaceutical Sciences, Osaka University, Osaka, Japan, ${ }^{2}$ Laboratory for System Biology and Medicine, The Research Center for Advanced Science and Technology, the University of Tokyo, Tokyo, Japan, ${ }^{3}$ Perseus Proteomics Inc, Tokyo, Japan and ${ }^{4}$ Graduate School of Medicine, Osaka University, Osaka, Japan

Email: Keisuke Tachibana - nya@phs.osaka-u.ac.jp; Yumi Kobayashi - doi@phs.osaka-u.ac.jp; Toshiya Tanaka - tanaka@med.rcast.u-tokyo.ac.jp; Masayuki Tagami - doi@phs.osaka-u.ac.jp; Akira Sugiyama - sakira-tky@umin.ac.jp; Tatsuya Katayama - doi@phs.osaka-u.ac.jp; Chihiro Ueda - doi@phs.osaka-u.ac.jp; Daisuke Yamasaki - yama045d@phs.osaka-u.ac.jp; Kenji Ishimoto - kenji@phs.osaka-u.ac.jp; Mikako Sumitomo - mikako-s@phs.osaka-u.ac.jp; Yasutoshi Uchiyama - yuchiyama@ppmx.com; Takahide Kohro - tkohro-tky@umin.ac.jp; Juro Sakai - jmsakai-tky@umin.ac.jp; Takao Hamakubo - hamakubo@ns.med.rcast.u-tokyo.ac.jp; Tatsuhiko Kodama - kodama@lsbm.org; Takefumi Doi* - doi@phs.osaka-u.ac.jp

* Corresponding author

Published: 03 October 2005

Nuclear Receptor 2005, 3:3 doi:10.1186/1478-1336-3-3
Received: 24 May 2005

Accepted: 03 October 2005

This article is available from: http://www.nuclear-receptor.com/content/3/I/3

(C) 2005 Tachibana et al; licensee BioMed Central Ltd.

This is an Open Access article distributed under the terms of the Creative Commons Attribution License (http://creativecommons.org/licenses/by/2.0), which permits unrestricted use, distribution, and reproduction in any medium, provided the original work is properly cited.

\begin{abstract}
Background: Peroxisome proliferator-activated receptors (PPARs) are ligand-activated transcription factors and commonly play an important role in the regulation of lipid homeostasis. To identify human PPARs-responsive genes, we established tetracycline-regulated human hepatoblastoma cell lines that can be induced to express each human PPAR and investigated the gene expression profiles of these cells.

Results: The expression of each introduced PPAR gene was investigated using the various concentrations of doxycycline in the culture media. We found that the expression of each PPAR subtype was tightly controlled by the concentration of doxycycline in these established cell lines. DNA microarray analyses using these cell lines were performed with or without adding each subtype ligand and provided much important information on the PPAR target genes involved in lipid metabolism, transport, storage and other activities. Interestingly, it was noted that while ligand-activated PPAR $\delta$ induced target gene expression, unliganded PPAR $\delta$ repressed these genes. The real-time RT-PCR was used to verify the altered expression of selected genes by PPARs and we found that these genes were induced to express in the same pattern as detected in the microarray analyses. Furthermore, we analysed the 5'-flanking region of the human adipose differentiation-related protein (adrp) gene that responded to all subtypes of PPARs. From the detailed analyses by reporter assays, the EMSAs, and ChIP assays, we determined the functional PPRE of the human adrp gene.
\end{abstract}

Conclusion: The results suggest that these cell lines are important tools used to identify the human PPARs-responsive genes. 


\section{Background}

The peroxisome proliferator-activated receptors (PPARs) are ligand-activated transcription factors that belong to the nuclear hormone receptor superfamily [1]. Three subtypes, PPAR $\alpha, \operatorname{PPAR} \beta / \delta$ and PPAR $\gamma$, have been identified and these subtypes with a high degree of sequence conservation of each subtype across various species, have been characterized. The DNA binding domains of the three subtypes are $80 \%$ identical, while their ligand-binding domains exhibit a lower degree (approx. 65\%) of identity. Consistent with this relatively high divergence among the subtype-specific ligand binding domains, differential activation of PPARs by endogenous and exogenous compounds may account for the specific biological activity of the three PPAR subtypes [2,3].

PPAR $\alpha$ is expressed in the liver, kidney, heart and muscle where it regulates energy homeostasis. PPAR $\alpha$ activates fatty acid catabolism, stimulates gluconeogenesis and ketone body synthesis and is involved in the control of lipoprotein assembly [4]. Although PPAR $\alpha$ is well characterized, the functional differences of PPAR $\alpha$ derived from species are not clear. For example, sustained PPAR $\alpha$ activation has carcinogenic consequences in the liver of rodents, but long-term usage of PPAR $\alpha$ activators in epidemiological data, has proven that similar effects are unlikely to occur in humans $[5,6]$. PPAR $\delta$ is expressed ubiquitously, and is implicated in fatty acid oxidation, in keratinocyte differentiation and wound healing, and in mediating very low density lipoprotein signalling of the macrophage [7-11]. However, the function of PPAR $\delta$ is less understood than PPAR $\alpha$ and $\gamma$. There are two PPAR $\gamma$ isoforms, PPAR $\gamma 1$ and $\gamma 2$ PPAR $\gamma 2$, which is generated by alternative splicing, contains an additional 28 amino acids at the N-terminal end relative to PPAR $\gamma 1$. PPAR $\gamma 3$ is a splicing variant of PPAR $\gamma 1$ and gives rise to the same protein. PPAR $\gamma 2$ is expressed exclusively in adipose tissue and has a pivotal role in adipocyte differentiation, lipid storage in the white adipose tissue and energy dissipation in the brown adipose tissue $[12,13]$. On the other hand, PPAR $\gamma 1$ is expressed in the liver and other tissues, and the expression of hepatic PPAR $\gamma$ is increased in some obese and diabetic model mice [14-17]. PPAR $\gamma$ is involved in glucose metabolism through the improvement of insulin sensitivity; however, its function is not well defined.

All PPARs bind to a direct repeat of two hexanucleotides, spaced by one or two nucleotides (the DR1 or DR2 motif) as heterodimers with the retinoid $\mathrm{X}$ receptor (RXR), and activate several target genes [18-20]. These peroxisome proliferator responsive elements (PPREs) are found in various genes that are involved in lipid metabolism and energy homeostasis, including lipid storage or catabolism, and fatty acid transport, uptake and intracellular binding [21].
One of the approaches for investigating target genes of PPARs is to construct stable cell lines that can be induced to express PPARs. The tet-off system is a well-established system for inducible gene expression. In this system, transcription is turned on or off in response to doxycycline (Dox; a tetracycline derivative) in a strictly dose-dependent manner. Therefore, background or leaky expression in the absence of induction is extremely low. The tet-off system enables us to compare the same cell line before and after induction of the gene of interest. Previously, we established the human hepatoblastoma cell lines (HepG2 cells) which were strictly induced to express the hepatitis $\mathrm{C}$ non-structural proteins by removing Dox from the media, and we characterized the changes in mRNA expression profile using DNA microarray analyses [22].

In the present study, to identify human PPARs-responsive genes in the liver cell line, we established tightly tet-regulatable HepG2 cells which can be induced to express each human PPAR. We demonstrated that human PPARs are important regulators of lipid homeostasis in these cell lines using DNA microarray and real-time RT-PCR technologies. Subsequent analyses revealed that all PPARs induced human adipose differentiation-related protein (adrp) gene expression through the same PPRE of the ADRP promoter, while unliganded PPAR $\delta$ repressed this gene. Our results imply that these cell lines are important tools, which can be used to identify the human PPARs-responsive genes.

\section{Results \\ Establishment of HepG2 cells that can be induced to express PPARs}

To identify human PPARs-responsive genes, we established each cell line that expresses any one of the PPAR subtypes $(\alpha, \beta / \delta, \gamma 1$ or $\gamma 2)$ using the tet-regulated system. Previously, we established the tightly tet-regulatable HepG2 cell clone (HY-Toff) which was transfected with the pTet-off vector, and that this clone had a large induction/repression rate [22]. The tet-off regulatable HY-Toff cells were transfected with the pBabepuro (for puromycin resistance) and PBI-EGFP vector harbouring the cDNA for human PPAR $\alpha, \operatorname{PPAR} \delta, \operatorname{PPAR} \gamma 1$ or PPAR $\gamma 2$. We picked out puromycin-resistant clones. Among these clones, we selected the strictly responsive cell lines (HepG2-tet-offhPPAR cells) to the concentration of Dox. These cell lines were cultured in the presence of Dox at $0,0.01,0.1$ or $1000 \mathrm{ng} / \mathrm{ml}$ for 5 days, and we found that PPARs expression in these cell lines was induced in a dose-dependent manner (Figure $1 \mathrm{~A}-\mathrm{D}$ ). We then examined the time course experiment of each PPAR expression after the removal of Dox. The results showed that both the mRNA (Figure 2A-D) and protein (Figure 2E-H) levels of each PPAR were increased after the removal of Dox from the culture medium. Under these conditions, cell 


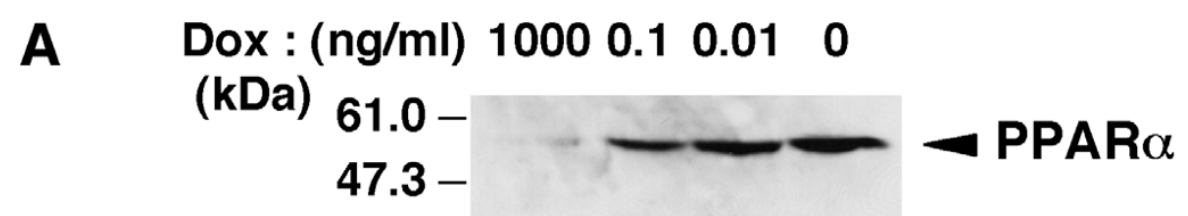

HepG2-tet-off-hPPAR $\alpha$

B Dox : (ng/ml) $1000 \quad 0.10 .01 \quad 0$

(kDa) $61.0-$
$47.3-$

HepG2-tet-off-hPPAR $\delta$

C Dox : (ng/ml) 10000.10 .010

(kDa)

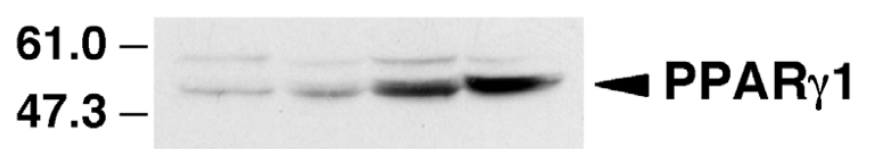

HepG2-tet-off-hPPAR 1

D Dox : (ng/ml) 10000.10 .010

(kDa) $61.0-$

- PPAR $\gamma 2$

$47.3-$

\section{HepG2-tet-off-hPPAR $\gamma 2$}

Figure I

Induction of the expression of PPAR by doxycycline in established cell lines. $A, B, C$ and $D$, Nuclear extracts $(50 \mu g$ protein/lane) from each cell line cultured in the presence of the indicated amounts of Dox for 5 days were subjected to SDSPAGE and immunoblots were performed with anti-PPAR $\alpha(A)$, anti-PPAR $\delta(B)$ or anti-PPAR $\gamma(C$ and D). 
A

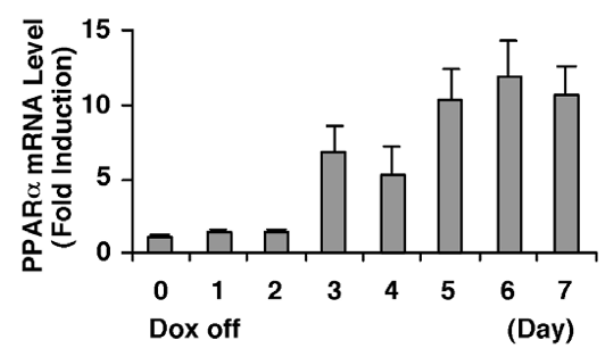

C

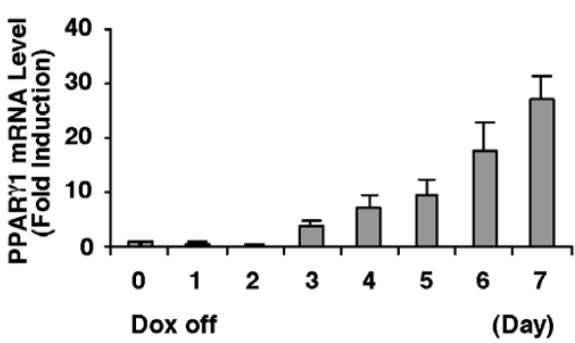

B

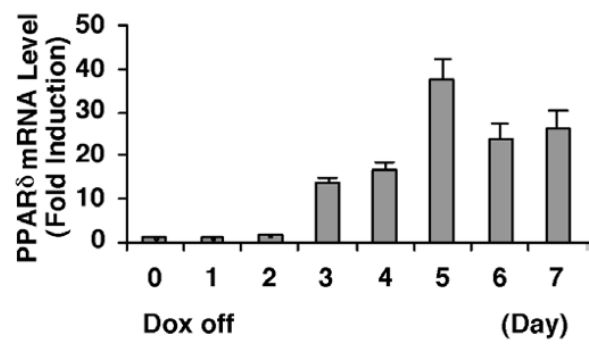

D

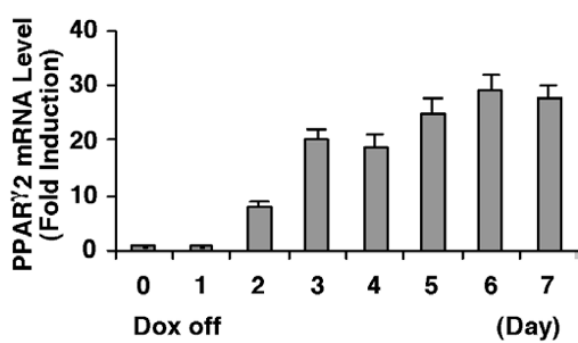

$\mathbf{E}$

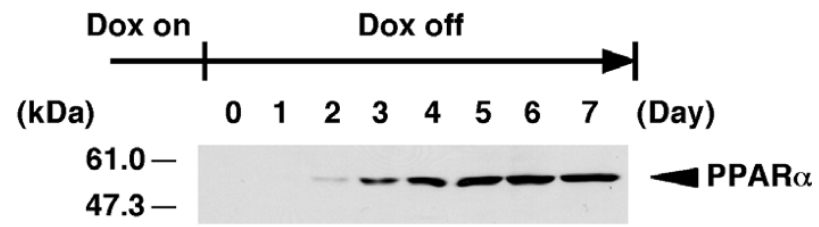

F

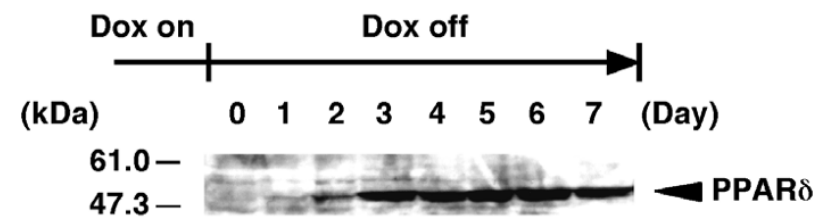

G

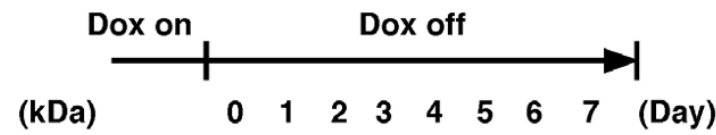

(kDa)

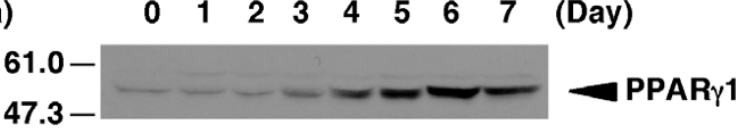

H

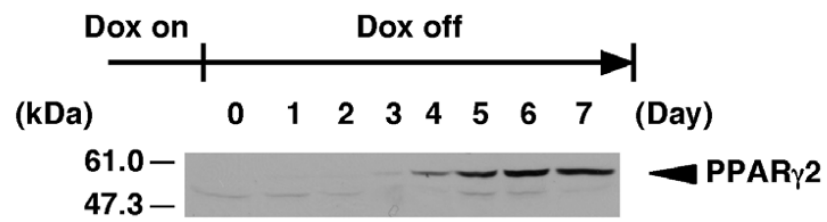

Figure 2

Time course of PPAR expression in established cell lines. A, B, $C$ and $D$, The cell lines for the expression of PPAR $\alpha$ (A), PPAR $\delta$ (B), PPAR $\gamma$ I (C) or PPAR $\gamma 2$ (D) were cultured in the presence of Dox. At time point 0 , Dox was removed from the medium. The total RNAs were extracted from the cells cultured for the indicated days after removal of Dox and the amount of mRNAs of PPARs were measured by real time RT-PCR. Values are expressed as the mean \pm S.E.M. $(n=3)$, relative to the control ( 0 day) set as I. E, $F, G$ and $H$, Nuclear extracts ( $50 \mu \mathrm{g}$ protein/lane) from the cell lines expressing PPAR $\alpha$ (E), PPAR $\delta$ $(F)$, PPAR $\gamma$ I $(G)$ or PPAR $\gamma 2(H)$ cultured for the indicated days after removal of Dox were subjected to SDS-PAGE and immunoblots were performed with anti-PPAR $\alpha(E)$, anti-PPAR $\delta(F)$ or anti-PPAR $\gamma(G$ and $H)$. 
Table I: Changes in mRNA expression levels of metabolism-related genes in HepG2-tet-off-hPPAR cells by ligands. Microarray analyses were performed on HepG2-tet-offhPPAR cells; the cells were cultured in the presence (Dox) or absence of Dox for 5 days. In the absence of Dox, the cells were treated with PPAR ligands (I00 $\mu M$ fenofibric acid for PPAR $\alpha$ (Feno), $100 \mathrm{nM}$ GW50 1516 for PPAR $\delta$ (GW) or $10 \mu$ M ciglitizone for PPAR $\gamma$ (Cig)) or vehicle (DMSO) for $24 \mathrm{~h}$. Gene expression profiles were compared between DMSO and Dox (DMSO versus Dox), ligands and Dox (Feno versus Dox, GW versus Dox, and Cig versus Dox were indicated in the case of PPAR $\alpha$, PPAR $\delta$ and PPAR $\gamma$,

respectively) or ligands and DMSO (Feno versus DMSO, GW versus DMSO, and Cig versus DMSO were indicated in the case of PPAR $\alpha$, PPAR $\delta$ and PPAR $\gamma$, respectively). Samples were analysed using GeneChip ${ }^{\circledR}$ software Microarray Suite (MAS) Ver.5.0 (Affymetrix).

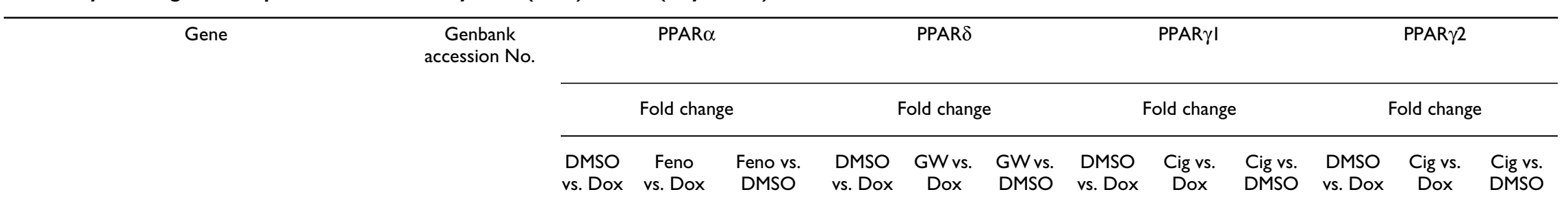

Fatty acid metabolism

acyl-CoA synthetase long-chain family member carnitine palmitoyltransferase IA (liver)

solute carrier family 25 (carnitine/acylcarnitine translocase), member 20

acyl-Coenzyme A dehydrogenase, very long

acyl-Coenzyme A dehydrogenase, C-4 to C-12 straight chain

hydroxyacyl-Coenzyme A dehydrogenase/3-

ketoacyl-Coenzyme A thiolase/enoyl-Coenzyme

A hydratase (trifunctional protein), alpha subunit

hydroxyacyl-Coenzyme A dehydrogenase/3-

ketoacyl-Coenzyme A thiolase/enoyl-Coenzyme

A hydratase (trifunctional protein), beta subunit acetyl-Coenzyme $A$ acyltransferase 2

(mitochondrial 3-oxoacyl-Coenzyme $\mathrm{A}$ thiolase) acetyl-Coenzyme $A$ acyltransferase I

(peroxisomal 3-oxoacyl-Coenzyme A thiolase)

enoyl Coenzyme A hydratase I, peroxisomal Antioxidant

catalase

vanin I

Ketogenesis

3-hydroxy-3-methylglutaryl-Coenzyme A

synthase 2 (mitochondrial)

$$
\text { Transport/strage }
$$

fatty acid binding protein I, liver

adipose differentiation-related protein

$\mathrm{C}$-terminal linking and modulating protein/PDZ

domain containing I

lipase, hepatic
NM 001995

NM 001876

NM 000387

NM 000018

NM 000016

NM 000182

NM 000183

NM 001607

NM 001398

NM 001752

NM 004666

NM 005518

1.84

1.48

$\begin{array}{ll}1.48 & 2.86 \\ 1.20 & 2.23\end{array}$

2.23

$2.16 \quad 3.46$

$\begin{array}{ll}1.62 & 2.52\end{array}$

$\begin{array}{ll}1.48 & 2.43\end{array}$

$1.74 \quad 2.66$

$1.58 \quad 1.92$

$1.42 \quad 1.62$

$2.28 \quad 2.61$

$1.51 \quad 2.36$

$\begin{array}{ll}5.07 & 12.92\end{array}$

$32.40 \quad 156.62$

NM 001443

NM 001122

NM 002614

NM 000236

$\begin{array}{llllllllll}1.90 & 0.82 & 1.72 & 2.09 & 0.88 & 2.30 & 2.60 & 0.82 & 1.00 & 1.23 \\ 1.93 & 0.37 & 2.05 & 5.60 & 0.74 & 1.35 & 1.83 & 1.12 & 1.24 & 1.10 \\ 1.85 & 0.91 & 1.36 & 1.50 & 0.83 & 0.93 & 1.12 & 1.04 & 1.27 & 1.22 \\ 1.60 & 0.92 & 2.69 & 2.93 & 1.36 & 1.97 & 1.45 & 1.55 & 2.33 & 1.50 \\ 1.56 & 0.64 & 2.03 & 3.16 & 1.24 & 1.48 & 1.20 & 1.40 & 1.80 & 1.29 \\ 1.65 & 0.89 & 1.49 & 1.66 & 1.34 & 1.62 & 1.21 & 1.41 & 2.29 & 1.62\end{array}$


Table I: Changes in mRNA expression levels of metabolism-related genes in HepG2-tet-off-hPPAR cells by ligands. Microarray analyses were performed on HepG2-tet-offhPPAR cells; the cells were cultured in the presence (Dox) or absence of Dox for 5 days. In the absence of Dox, the cells were treated with PPAR ligands (I00 $\mu M$ fenofibric acid for PPAR $\alpha$ (Feno), $100 \mathrm{nM}$ GW50 1516 for PPAR $\delta$ (GW) or $10 \mu$ ciglitizone for PPAR $\gamma($ Cig)) or vehicle (DMSO) for $24 \mathrm{~h}$. Gene expression profiles were compared between DMSO and Dox (DMSO versus Dox), ligands and Dox (Feno versus Dox, GW versus Dox, and Cig versus Dox were indicated in the case of PPAR $\alpha$, PPAR $\delta$ and PPAR $\gamma$,

respectively) or ligands and DMSO (Feno versus DMSO, GW versus DMSO, and Cig versus DMSO were indicated in the case of PPAR $\alpha$, PPAR $\delta$ and PPAR $\gamma$, respectively). Samples were analysed using GeneChip ${ }^{\circledR}$ software Microarray Suite (MAS) Ver.5.0 (Affymetrix). (Continued)

\begin{tabular}{|c|c|c|c|c|c|c|c|c|c|c|c|c|c|}
\hline aquaporin 3 & NM 004925 & 3.00 & 5.86 & 1.95 & 0.26 & 1.91 & 7.38 & 1.58 & 3.41 & 2.16 & 1.38 & 3.09 & $\overline{2.24}$ \\
\hline glycerol kinase & NM 000167 & 0.87 & 1.57 & 1.79 & 0.73 & 0.79 & 1.08 & 1.00 & 1.21 & 1.21 & 1.84 & 3.17 & 1.73 \\
\hline phosphoenolpyruvate carboxykinase I (soluble) & NM 002591 & 6.39 & 17.90 & 2.80 & 0.83 & 4.64 & 5.56 & 6.94 & 29.19 & 4.20 & 34.46 & 110.78 & 3.21 \\
\hline \multicolumn{14}{|l|}{ Metabolism } \\
\hline angiopoietin-like protein 4 & NM 016109 & 1.71 & 17.97 & 10.54 & 3.00 & 25.67 & 8.56 & 1.24 & 7.27 & 5.84 & 3.88 & 33.56 & 8.66 \\
\hline heme oxygenase (decycling) I & NM 002133 & 1.25 & 2.21 & 1.77 & 0.66 & 1.25 & 1.90 & 1.31 & 2.20 & 1.68 & 2.18 & 4.20 & 1.93 \\
\hline $\begin{array}{l}\text { biliverdin reductase } B \text { (flavin reductase } \\
(\mathrm{NADPH}) \text { ) }\end{array}$ & NM 000713 & 1.07 & 1.65 & 1.55 & 0.84 & 0.86 & 1.03 & 0.87 & 1.58 & 1.81 & 1.36 & 4.03 & 2.97 \\
\hline $\begin{array}{l}\text { sulfotransferase family, cytosolic, } 2 \mathrm{~A} \text {, } \\
\text { dehydroepiandrosterone (DHEA) -preferring, } \\
\text { member I }\end{array}$ & NM 003167 & 2.61 & 2.86 & 1.10 & 0.70 & 2.08 & 2.98 & 0.95 & 1.76 & 1.85 & I.7I & 1.68 & 0.98 \\
\hline abhydrolase domain containing 3 & NM 138340 & 1.68 & $3.5 \mathrm{I}$ & 2.08 & 0.54 & 2.16 & 3.96 & 1.76 & 3.30 & 1.88 & 2.01 & 3.99 & 1.99 \\
\hline
\end{tabular}


proliferation in these cell lines was not affected until 7 days after the removal of Dox. Based on these results, we decided that the expression of each PPAR on the 5th day was suitable for further analyses, such as the determination of the target genes of each PPAR subtype.

\section{Changes in mRNA expression profiles by the induction of each PPAR subtype with the PPAR ligands}

To characterize the regulation of gene expression by each PPAR subtype, we performed oligonucleotide microarray analyses. HepG2-tet-off-hPPAR cells were cultured in the presence or absence of Dox for 5 days, then treated with the PPAR ligands $(100 \mu \mathrm{M}$ fenofibric acid for PPAR $\alpha, 100$ $\mathrm{nM}$ GW501516 for PPAR $\delta$ or $10 \mu \mathrm{M}$ ciglitizone for PPAR $\gamma$ ) or vehicle for $24 \mathrm{~h}$. Total RNA samples were prepared from these cells, and oligonucleotide microarray analyses were performed using the Affymetrix HG-U133A arrays that contain $>22,000$ probe sets.

To identify human PPARs-responsive genes, we analysed the genes induced by ligand-activated PPARs. The criteria for selecting genes are described in the Methods section. Based on these criteria, 29, 21, 60 and 107 genes were upregulated by ligand-activated PPAR $\alpha$, PPAR $\delta$, PPAR $\gamma 1$ and PPAR $\gamma 2$, respectively. As shown in Table 1 and the additional file 1, each PPAR affects the expression levels of several genes involved in lipid metabolism, glucose homeostasis, etc. PPAR $\alpha$ tends to induce the expression of a number of genes involved in the $\beta$-oxidation of fatty acids by mitochondria, peroxisomal fatty acid oxidation, antioxidant and ketogenesis. Most of the genes that were induced by PPAR $\delta$ were similar to those exhibited by PPAR $\alpha$. We observed that induced expression of PPAR $\delta$ increased the expression in the presence of the ligand, while unliganded PPAR $\delta$ repressed the expression of its target genes instead. On the other hand, PPAR $\gamma$ tends to induce the expression of several genes involved in gluconeogenesis, lipid storage, transport and metabolism. Moreover, PPAR $\gamma$ is likely to induce several genes involved in angiogenesis, cytoskeleton organization, protein modification, regulation of transcription, signal transduction, etc.

\section{Verification of gene expression profiles with quantitative PCR analyses}

The expression of a subset of genes in response to treatment with PPAR ligands was further characterized using real-time quantitative PCR analyses. Total RNA samples were prepared from HepG2-tet-off-hPPAR cells, which were cultured in the presence or absence of Dox for 5 days, and subsequently treated with the PPAR ligands $(100 \mu \mathrm{M}$ fenofibric acid, $100 \mathrm{nM}$ GW501516 or $10 \mu \mathrm{M}$ ciglitizone for PPAR $\alpha$, PPAR $\delta$ and PPAR $\gamma$, respectively) or vehicle for $0,8,24,48$ or $72 \mathrm{~h}$. Several PPAR-responsive genes (ADRP, 3-hydroxy-3-methylglutaryl-Coenzyme A synthase 2 (mitochondrial) (HMGCS2), hydroxyacylCoenzyme A dehydrogenase/3-ketoacyl-Coenzyme A thiolase/enoyl-Coenzyme A hydratase (trifunctional protein), $\alpha$ subunit (HADHA), phosphoenolpyruvate carboxykinase 1 (PEPCK), acyl-Coenzyme A dehydrogenase, C-4 to C-12 straight chain (MCAD), angiopoietinlike protein 4 (ANGPTL4), fatty acid binding protein 1, liver (L-FABP)) were up-regulated by the expression of PPAR $\alpha$ and PPAR $\gamma$ (Figure 3). On the other hand, only ligand-activated PPAR $\delta$ induced the expression of these genes, but unliganded PPAR $\delta$ repressed them, in agreement with microarray analyses (Figure 3B and Table 1).

Although until now C-terminal linking and modulating protein/PDZ domain containing 1 (CLAMP/PDZK1) mRNA has not been reported as a target for PPARs, we observed that PPARs induced CLAMP/PDZK1 mRNA by microarray analyses (Table 1 ). We, therefore, verified the expression of CLAMP/PDZK1 mRNA using real-time quantitative PCR analysis. A similar result was observed on the expression pattern of CLAMP/PDZK1 mRNA (Figure 3).

Although all subtypes of PPARs could induce the expression of these genes, PPAR $\alpha$ was more effective than other subtypes in the real-time PCR analyses (Figure 3).

\section{PPARs modulate human ADRP promoter activity via a PPRE}

To determine whether one of these genes was regulated by PPARs directly, we performed transient transfection experiments with the human ADRP promoter. It has been reported that the mouse ADRP promoter contains a functional PPRE [11]. Examination of the corresponding region of the human adrp gene indicated that the essential features of this element are likely to be conserved, and we found that the human ADRP promoter contained a potential PPRE at positions -2361 to -2345 (Figure 4A).

To analyse whether this site can be regulated by PPARs, either the wild type 4-kb fragment of the human ADRP promoter (hADRP-4K), deletion promoter (hADRP-d1) whose potential PPRE is deleted or mutation promoter (hADRP-mut) whose potential PPRE is mutated, was cloned in front of the pGL3-luciferase reporter gene to construct reporter plasmids (Figure 4B). We co-transfected either the PPAR expression plasmid (pcDNA3-hPPAR $\alpha$, pcDNA3-hPPAR $\delta$ pCDNA3-hPPAR $\gamma 1$ or pcDNA3hPPAR $\gamma 2$ ) or the vector plasmid (pcDNA3) as a control together with each reporter plasmid into HepG2 cells, and subsequently incubated these cells with or without ligands $(100 \mu \mathrm{M}$ fenofibric acid, $100 \mathrm{nM}$ GW501516 or 10 $\mu \mathrm{M}$ ciglitizone for PPAR $\alpha, \operatorname{PPAR} \delta$ and PPAR $\gamma$, respectively) for $24 \mathrm{~h}$. Ligand-activated PPARs induced the promoter activity of the wild type 2 to 5 -fold higher than the 

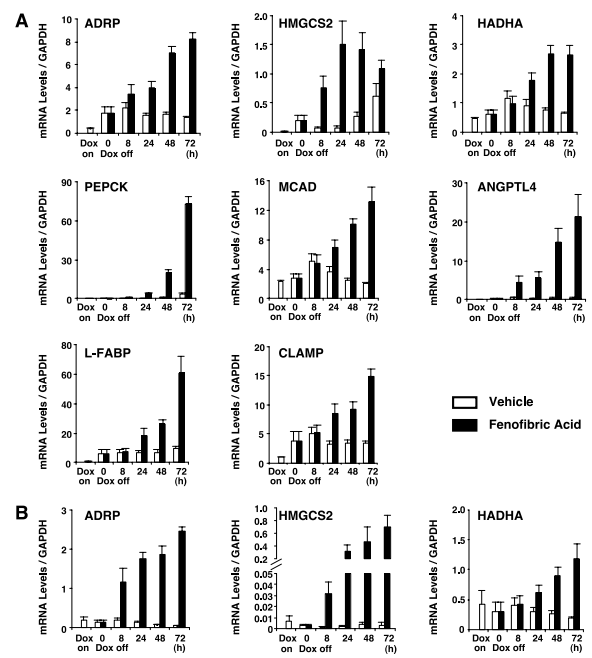

$\square$ vehicle
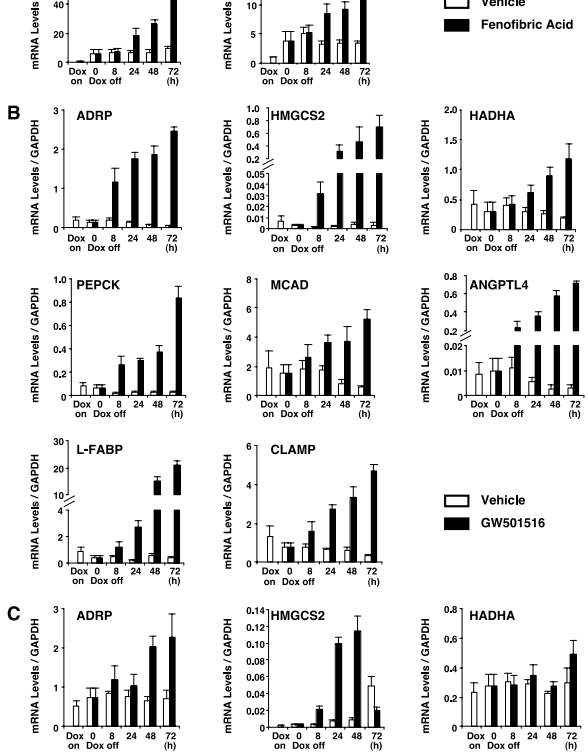

घWhicle
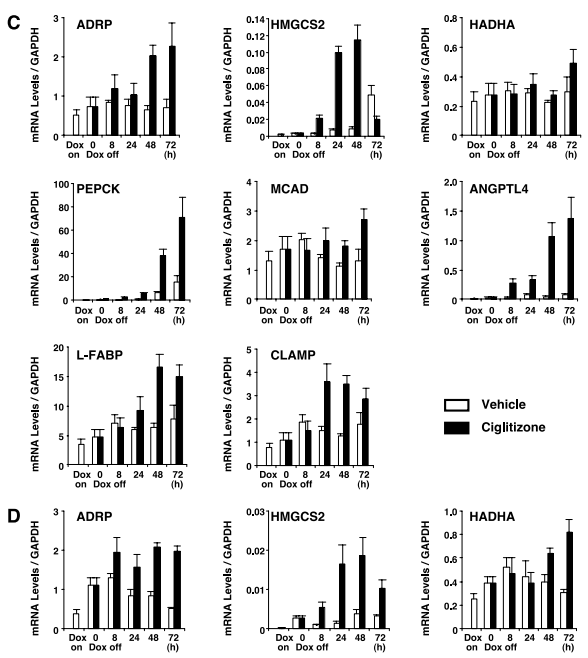

$\square$ vehicle
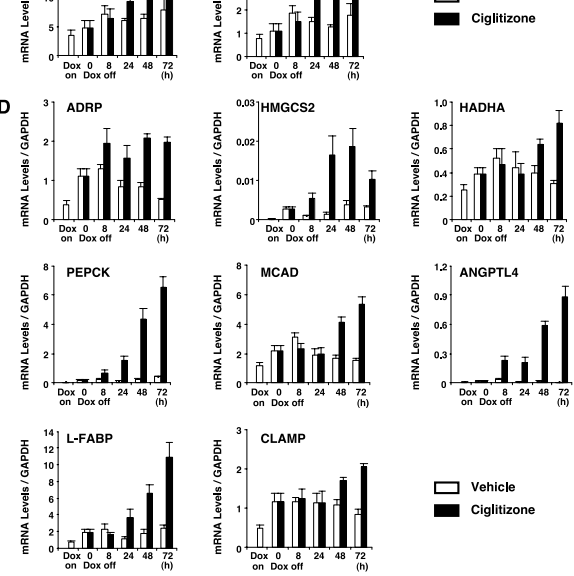

Figure 3

Eight gene expressions were modulated by PPARs in tet-regulated HepG2 cells. $A, B, C$ and $D$, HepG2-tet-offhPPAR cells were treated with DMSO (vehicle) or PPAR ligands (100 $\mu$ M fenofibric acid for PPAR $\alpha$ (A), $100 \mathrm{nM}$ GW501516 for PPARS (B), $10 \mu \mathrm{M}$ ciglitizone for PPAR $\gamma \mathrm{l}$ (C) or PPAR $\gamma 2$ (D)) for 0, 8, 24, 48 or $72 \mathrm{~h}$ in the absence of Dox. Messenger RNA levels of human ADRP, HMGCS2, HADHA, PEPCK, MCAD, ANGPTL4, L-FABP and CLAMP/PDZKI were measured by real time RT-PCR. Values are expressed as mean \pm S.E.M. $(n=3)$ target mRNA levels normalized to GAPDH mRNA. 
A

\begin{tabular}{|c|c|c|c|c|c|c|}
\hline \multirow[b]{3}{*}{$\begin{array}{l}\text { Consensus : } \\
\text { mouse ADRP : }\end{array}$} & \multirow[b]{3}{*}{-2013} & \multirow[b]{3}{*}{$\begin{array}{l}\text { GCCTT } \\
\star \star \star \star \star\end{array}$} & \multicolumn{2}{|r|}{ PPRE } & \multirow[b]{3}{*}{$\begin{array}{l}\text { AAGAAA } \\
\star\end{array}$} & \multirow[b]{3}{*}{-1986} \\
\hline & & & 5'Flank & DR1 & & \\
\hline & & & $\begin{array}{l}\text { WWCW } \\
\text { TTGT } \\
\star \star \star \star\end{array}$ & $\begin{array}{l}\text { RGGKMA A } \text { AGKTCA } \\
\text { AGGTGA A } \text { AGGGCA } \\
\star \star \star \star \star \star \star \star \star \star \star \star \star \star \star\end{array}$ & & \\
\hline human ADRP : & -2366 & GCATT & TTGT & AGGTGA A AGGGCG & AGAGTC & -2339 \\
\hline
\end{tabular}

B

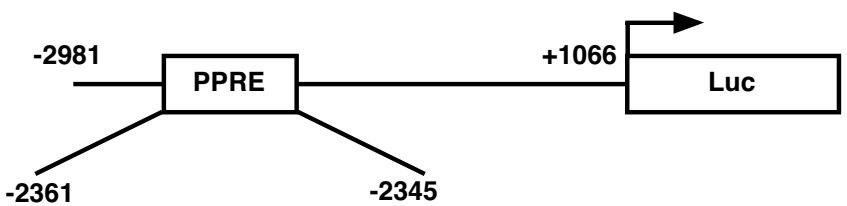

hADRP-4K TTGT AGGTGA A AGGGCG

hADRP-mut ccGc AaGctt A AGGGCG

hADRP-d1 -2345

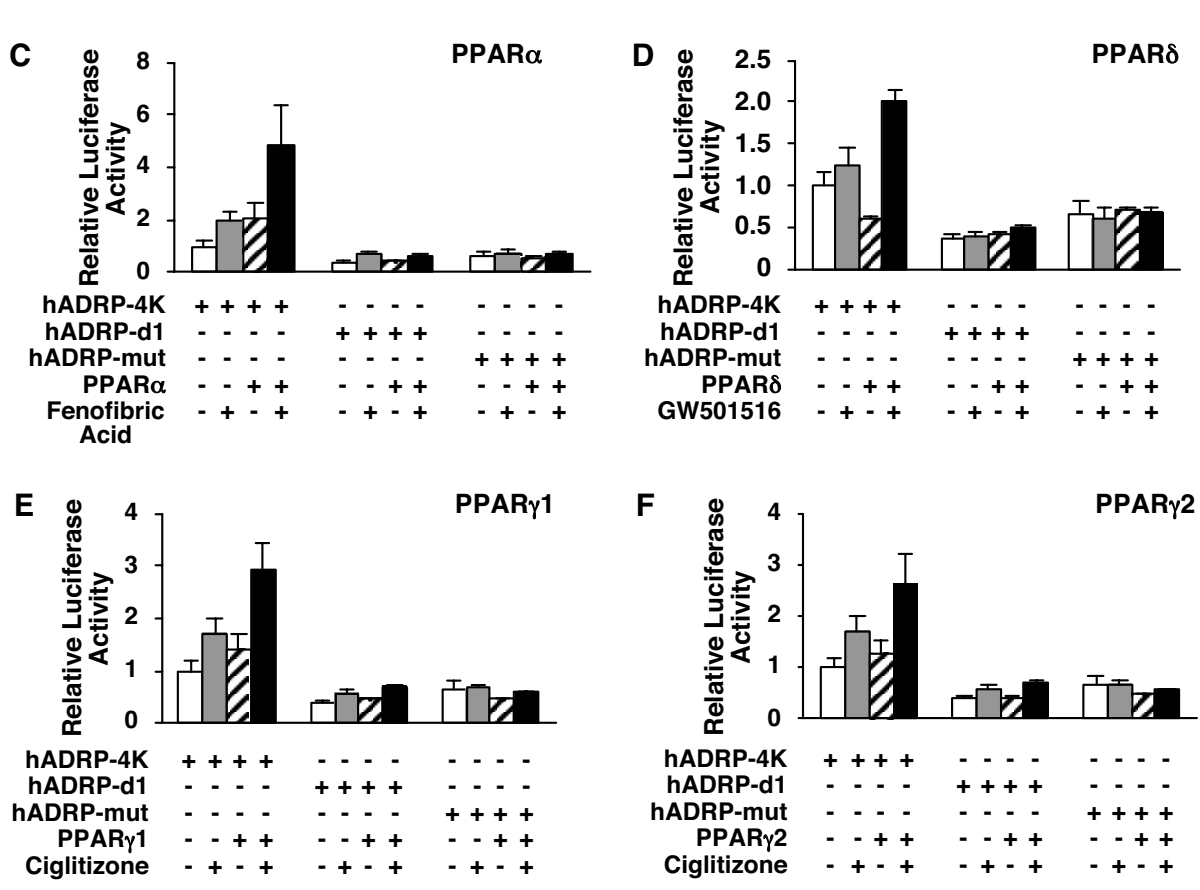

Figure 4

PPARs modulate human ADRP promoter activity via a PPRE located between $\mathbf{- 2 3 6 I}$ and $\mathbf{- 2 3 4 5}$ bp. A, $\mathrm{A}$ sequence corresponding to the $-2366 /-2339$ region of the human adrp gene, was compared with a consensus PPRE and the analogous regions in the mouse adrp gene promoter (-20I3/-1986). A human ADRPmut indicates a human ADRP promoter whose potential PPRE was mutated. Asterisks denote conserved bases and arrows represent response element half-sites. $B$, Schematic representation of the chimeric genes containing the human ADRP promoters; each wild type (hADRP-4K), point mutation (hADRP-mut), and deletion (hADRP-dI) of the ADRP promoter was cloned in front of the firefly luciferase reporter gene. Lowercase letters indicate mutations introduced in the human ADRP PPRE. $C, D, E$ and $F$, HepG2 cells were co-transfected with a human ADRP reporter plasmid (50 ng), phRL-TK (50 ng) and either pcDNA3-hPPAR $\alpha$ (5 ng) (C), pcDNA3-hPPAR $\delta$ (5 ng) (D), pcDNA3-hPPAR $\gamma \mathrm{l}$ (5 ng) (E) or pcDNA3-hPPAR $\gamma 2$ (5 ng) (F). Transfected cells were treated with ligands (I00 $\mu M$ fenofibric acid (C), $100 \mathrm{nM} \mathrm{GW50I5I6}$ (D) or $10 \mu \mathrm{M}$ ciglitizone (E and F)) for $24 \mathrm{~h}$ and the cells were used for reporter gene assays. Luciferase activities from reporter plasmids were normalized by internal Renilla luciferase activity. Values are expressed as fold induction of the control (the value when only reporter plasmid (ADRP-4K) was transfected) set at I. Values represent the mean \pm S.E.M. $(n=3)$. 
control (no PPAR expression without ligand) (Figure 4CF). Interestingly, the expression of PPAR $\delta$ without ligand diminished the wild type ADRP reporter gene expression to about $60 \%$ of the control in HepG2 cells (Figure 4D). We did not detect this observation when either deleted or mutated PPRE reporter plasmid was used. These data indicate that this PPRE in the ADRP promoter is a cis-acting element by which PPARs modulate human ADRP promoter activity.

To determine whether human PPARs/RXR $\alpha$ heterodimers bind this PPRE in the ADRP promoter, EMSAs were performed using this response element as a radiolabelled probe (Figure 5A-D). EMSAs revealed that all PPAR subtypes could bind the PPRE of the ADRP promoter in the presence of RXR $\alpha$ (closed arrowhead on lanes 2 to 4 ). Furthermore, these complexes were supershifted by antiPPAR antibodies (open arrowhead on lane 5). This complex formation was competed by increasing amounts (10and 100-fold excess) of unlabeled self-competitor (ADRP) and rat acyl CoA oxidase (ACO) PPRE fragments, but not by the mutated PPRE (ADRPmut) probes (lanes 6 to 11). Furthermore, no protein-DNA complex was observed when using the mutated PPRE (ADRPmut) probe (lane 12). Taken together, these data demonstrate that all PPARs bind to the same PPRE site at the position -2361 to -2345 , and modulate human ADRP promoter activity.

To confirm that the PPARs/RXR $\alpha$ heterodimers bind to the PPRE in the ADRP promoter in vivo, we performed chromatin immunoprecipitation (ChIP) assays using an anti-PPAR $\alpha$, anti-PPAR $\delta$, anti-PPAR $\gamma$, or anti-RXR $\alpha$ antibody. HepG2-tet-off-hPPAR cells were cultured in the absence of Dox for 5 days, and were subsequently treated with the PPAR ligands $(100 \mu \mathrm{M}$ fenofibric acid, $100 \mathrm{nM}$ GW501516 or $10 \mu \mathrm{M}$ troglitazone for PPAR $\alpha$, PPAR $\delta$ and PPAR $\gamma$, respectively) for $8 \mathrm{~h}$ and subsequently used for ChIP assays. PPARs/RXR $\alpha$ heterodimers bound to the PPRE in the ADRP promoter in vivo (Figure 6).

\section{Discussion}

In the present study, in order to identify human PPARsresponsive genes in the liver, we have established tightly tet-regulatable human hepatoblastoma cell lines that can be induced to express each human PPAR (HepG2-tet-offhPPAR cells). DNA microarray and real-time RT-PCR analyses using these stable cell lines indicate that PPARs activate gene expression involved in lipid metabolism, glucose homeostasis, and other activities (Table 1 and Figure 3). Cell proliferation of these cell lines was not affected until 7 days after removal of Dox. However, further investigation is required to define the influence of the expression of PPARs on the proliferation of these cell lines.
We identified a series of genes that are critical for many aspects of carbohydrate and lipid metabolism, including intracellular fatty acid transport, mitochondrial fatty acid $\beta$-oxidation, and ketogenesis by PPAR $\alpha$ (Table 1). Indeed, PPAR $\alpha$ regulates the expression of genes that encode for enzymes involved in peroxisomal proliferation and fatty acid oxidation in peroxisomes and mitochondria [2]. In addition, PPREs are present in the promoter region or the intronic sequence of these target genes [4]. However, our results show that PPAR $\alpha$ and other PPAR subtypes induce expression of these genes. In fact, liver PPAR $\gamma$ regulated the expression levels of genes involved in lipogenesis, fatty acid transport, storage, and oxidation using both wild type mice and adipose-deficient mice [23]. Other reports also showed that PPAR $\delta$ induced fatty acid oxidation by regulating genes involved in fatty acid transport, $\beta$ oxidation, and mitochondrial respiration in various tissues [7-9]. These reports support our results whereby each PPAR subtype induces fatty acid oxidation in the hepatoblastoma cell lines. In the real-time PCR analyses PPAR $\alpha$ was more effective than other subtypes in the hepatoblastoma cell lines, although all subtypes could induce the expression of these genes (Figure 3). Thus, we assume that PPAR $\alpha$ plays a major role in the liver, however, the mechanism of this effect remains uncertain.

Mammalian cells use glucose as a major energy source, and the origin of hepatic glucose production shifts from mainly glycogenolysis to gluconeogenesis as fasting prolongs to maintain blood glucose levels. The main precursors for hepatic gluconeogenesis are lactate, pyruvate, glycerol and alanine, which are converted into glucose via a series of reactions in the cytosol and mitochondria. PPAR $\alpha$ plays a pivotal role in the management of energy stores during fasting [2]. Indeed, PPAR $\alpha$-null mice, fasted for $24 \mathrm{~h}$, exhibit severe hypoglycaemia $[24,25]$. Recently, Patsouris et al. demonstrated that PPAR $\alpha$ stimulates the expression of a set of genes involved in hepatic gluconeogenesis from glycerol [26]. In the present study, glycerol kinase and glycerol transporter aquaporin 3 were up-regulated by the liganded PPARs. Surprisingly, an unexpected finding was that the PEPCK was up-regulated by PPARs in these cell lines. PEPCK catalyses the rate-limiting step in liver gluconeogenesis. Way et al. showed that when Zucker diabetic fatty rats were treated with PPAR $\gamma$ agonists, PEPCK expression was decreased in the liver, and suggested that PPAR $\gamma$ agonists decrease gluconeogenesis [27]. Although we cannot fully explain this inconsistency, there are several reports, which support our results. An in vivo study showed that PEPCK mRNA levels are elevated in the livers of dexamethasone (DEX)-treated PPAR $\alpha+/+$ mice, and not DEX-treated PPAR $\alpha-/-$ mice, and that PEPCK is increased when hepatic PPAR $\alpha$ expression is reconstituted in DEX-treated PPAR $\alpha$-/-LDLR-/- mice. Furthermore, the combination of DEX and the potent PPAR $\alpha$ ligand 


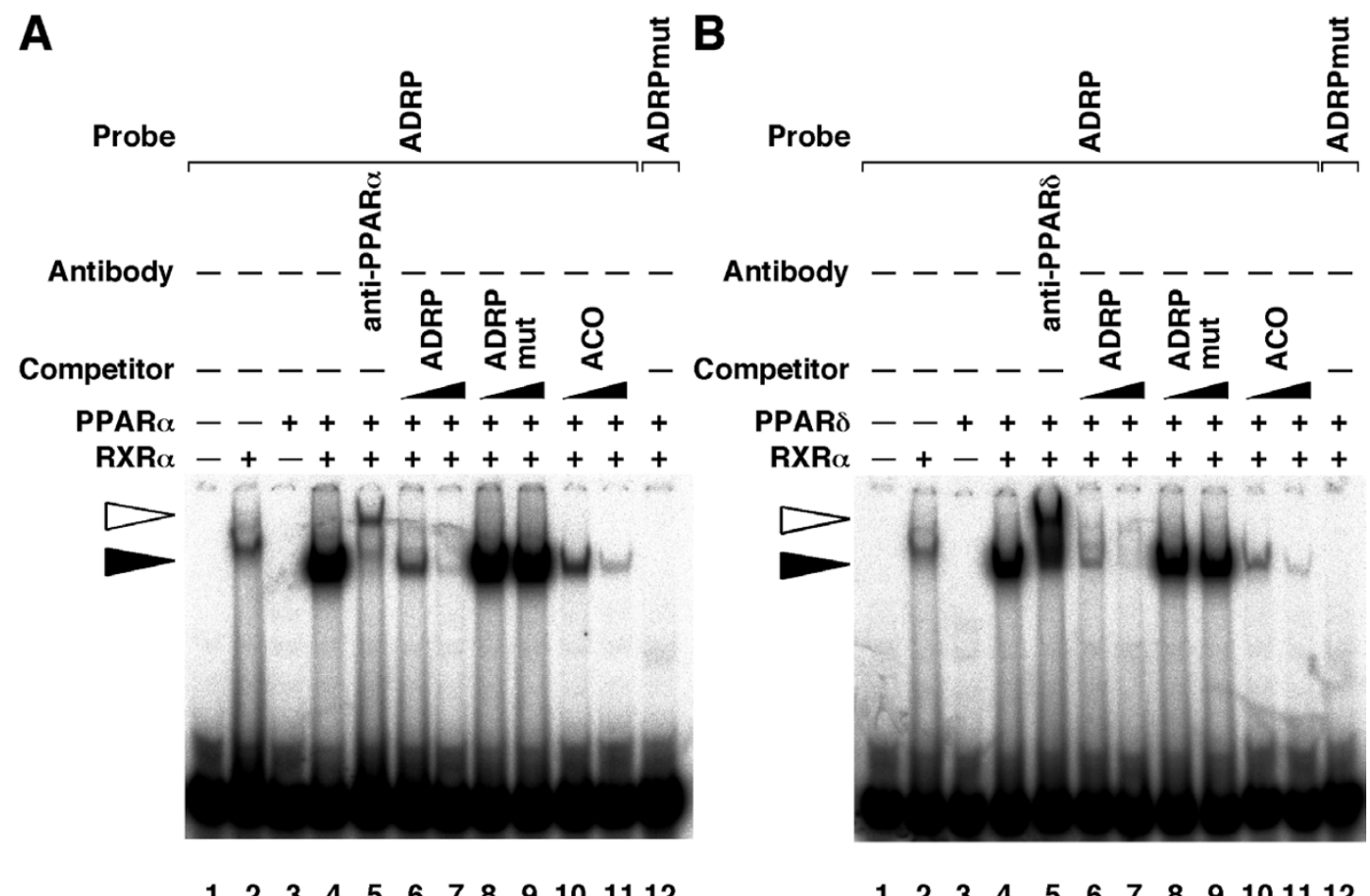

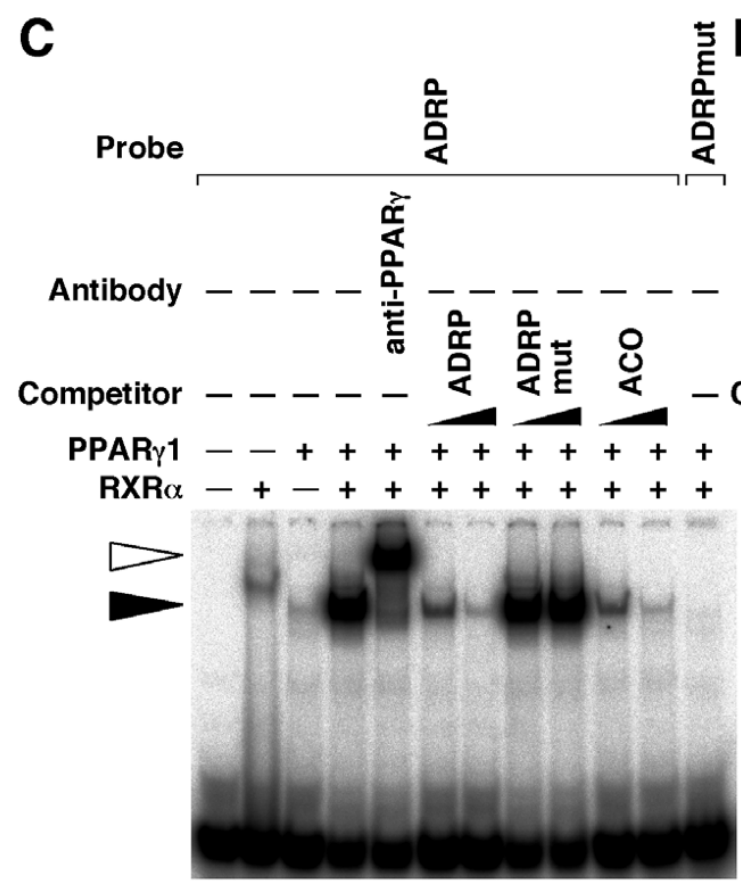

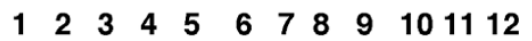

D
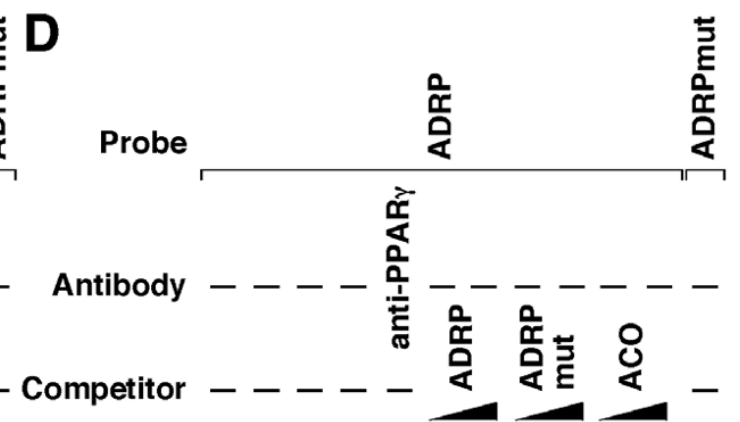

PPAR $2--+++t++++++$

$\operatorname{RXR} \alpha-++++++++++$

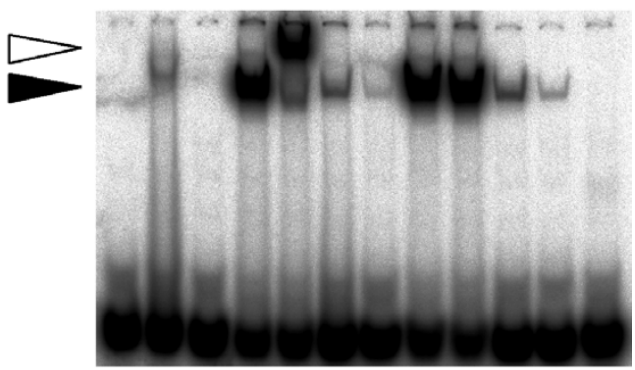

$\begin{array}{lllllllllllll}1 & 2 & 3 & 4 & 5 & 6 & 7 & 8 & 9 & 10 & 11 & 12\end{array}$

Figure 5

PPARs bind to the PPRE in the -2366/-2339 region of the human adrp gene. $A, B, C$ and $D$, EMSAs were performed with 32P-labelled either ADRP or mutated ADRP (ADRPmut) oligonucleotides in the presence of purified PPAR $\alpha$ (A), purified PPAR $\delta$ (B), in vitro transcribed/translated PPAR $\gamma \mathrm{I}(\mathrm{C})$, purified PPAR $\gamma 2(D)$ and/or purified RXR $\alpha$ proteins. Supershift experiments were carried out using anti-PPAR $\alpha(A)$, anti-PPAR $\delta(B)$ or anti-PPAR $\gamma(C$ and $D)$ antibodies. Unlabelled oligonucleotides (ADRP, ADRPmut or ACO) were used at 10 - or 100 -fold molar excess to the labelled probe to perform competition assays. Closed and open arrowheads indicate the specific bands and the supershift bands, respectively. 


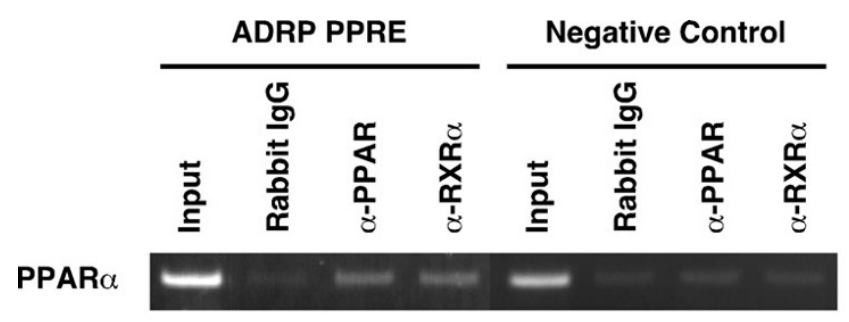

PPAR

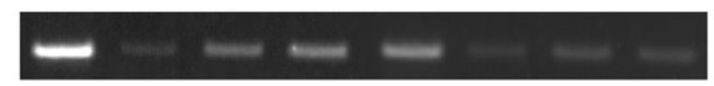

PPAR 1

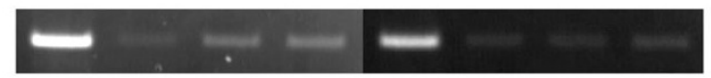

PPAR $\gamma 2$

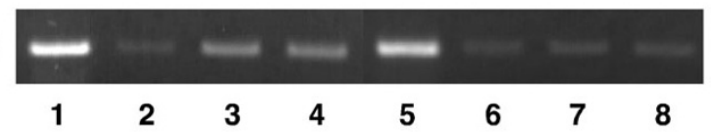

Figure 6

Chromatin immunoprecipitation assays of the ADRP promoter. HepG2-tet-off-hPPAR cells were treated with PPAR ligands (I00 $\mu \mathrm{M}$ fenofibric acid for PPAR $\alpha, 100 \mathrm{nM}$ GW50I5I6 for PPAR $\delta$, or $10 \mu M$ troglitazone for PPAR $\gamma$ ) for $8 \mathrm{~h}$ in the absence of Dox and processed for the ChIP assays. Soluble chromatin was immunoprecipitated with preimmune rabbit IgG (lanes 2 and 6), anti-PPAR antibodies (lanes 3 and 7), or anti-RXR $\alpha$ antibody (lanes 4 and 8). Immunoprecipitates were subjected to PCR with a primerpair specific to the ADRP promoter. As a negative control, a second set of primers were used to amplify another genomic region that was not expected to interact with the PPARs. PCR was performed with total chromatin input (lanes I and 5).

Wy14,643 increased the expression of PEPCK in human hepatocytes [28]. However, the reason for this differential induction remains unknown.

CLAMP, a four-PDZ-domain-containing protein also called PDZK1 [29], was identified as the scavenger receptor class B type I (SR-BI)-associated protein from rat liver membrane extracts [30]. CLAMP/PDZK1 regulates the stable SR-BI protein expression by a post-transcriptional mechanism [31]. The hepatic expression of SR-BI plays a critical role in lipoprotein metabolism, mainly due to its ability to mediate selective high density lipoproteins (HDL) cholesterol uptake [32,33]. HDL removes cholesterol from peripheral tissues and then transfers it to the liver. CLAMP/PDZK1 may modulate the intracellular transport and metabolism of cholesteryl esters taken up from HDL. Although until now, clamp/pdzk1 has not been reported as a direct PPAR target gene, we observed that CLAMP/PDZK1 mRNA was induced by PPARs in the established cell lines (Table 1 and Figure 3 ). These data suggest that CLAMP/PDZK1 is a target gene of PPARs. In the case of humans, PPRE exists in the CLAMP/PDZK1 promoter and PPARs can directly bind to this region (unpublished data). Therefore, PPAR activators may play a role in the regulation of HDL metabolism. However, further investigations are required to define the molecular mechanisms underlying the PPAR-mediated HDL metabolism.

Our microarray analyses indicated that there are many genes which are induced by all PPAR subtypes (Table 1, additional file 1). However, PPAR $\alpha$ and PPAR $\delta$ tend to induce the expression of a number of genes involved in the $\beta$-oxidation of fatty acids by mitochondria and peroxisomal fatty acid oxidation, and PPAR $\gamma$ tends to induce the expression of several genes involved in gluconeogenesis, lipid storage, transport and metabolism. Interestingly, we also observed that the genes involved in angiogenesis, cytoskeleton organization, signal transduction, protein modification and regulation of transcription were up-regulated in our HepG2-tet-off-hPPAR $\gamma$ cell lines. Indeed, there are several reports that PPAR $\gamma$ ligands modulate angiogenesis [34]. Further investigation is necessary to certify the subtype specific function of PPARs.

In the present study, we also observed that ligand-activated PPAR $\delta$ induced target gene expression, however, unliganded PPAR $\delta$ repressed these genes in the established cell lines (Table 1, Figures 3, 4). It has been reported that unliganded PPAR $\delta$ binds to PPRE and recruits corepressors, such as a silencing mediator for retinoid and thyroid hormone receptor (SMRT), nuclear receptor corepressor (NCoR) etc. On the other hand, liganded PPAR $\delta$ is thought to release the corepressor and form a complex with coactivators $[35,36]$. From this viewpoint, these established cell lines have a potential application to provide a high-throughput screening to detect the PPAR ligands (see below).

To further investigate the regulation of target gene expression by PPARs, we analysed the human ADRP promoter in detail. ADRP, expressed ubiquitously, is a protein covering lipid droplets [37]. The mouse adrp gene exhibits a PPRE between -2004 and -1992 bp that binds PPARs/RXR heterodimers [11]. The sequence of the corresponding response element in the human gene between -2361 and $-2345 \mathrm{bp}$ is very similar to the mouse PPRE (Figure 4A). We performed EMSAs with this element and all PPAR subtypes bound to the same PPRE site of the ADRP promoter (Figure 5). Moreover, this human PPRE site confers transactivation by PPARs to a luciferase reporter gene, and mutations that disrupt the binding sequence of PPARs/ 
RXR on this PPRE abolish transactivation (Figure 4). During the preparation of this manuscript, it was reported that the ADRP PPRE was the functional PPAR binding site and could be activated by human PPAR $\alpha$ and $\delta$ [38]. In the present study, we showed the same result and that PPAR $\gamma 1$ and $\gamma 2$ can also bind to PPRE and regulate the expression of the human adrp gene. Moreover, we were the first to confirm that PPARs/RXR $\alpha$ heterodimers bind to the PPRE in the ADRP promoter in vivo using ChIP assays (Figure 6).

PPARs are linked to metabolic disorders and, therefore, are interesting pharmaceutical targets. Among the synthetic ligands that activate these receptors, the fibrates are hypolipidemic compounds that activate PPAR $\alpha$. The thiazolidinediones, which selectively activate PPAR $\gamma$, are hypoglycaemic molecules that are used to treat type II diabetes. Recently, we and other groups reported that PPAR $\delta$ agonists might form effective drugs for obesity, diabetes, and cardiovascular disease $[7-9,39,40]$. From this viewpoint, these established cell lines have a potential application in various high-throughput assays. For instance, the reporter gene assay using the reporter plasmid containing the ADRP promoter would provide a useful detection system of PPAR $\delta$ ligands as potential drug candidates in the HepG2-tet-off-hPPAR $\delta$ cell line [41].

\section{Conclusion}

In conclusion, we established tightly tet-regulatable human hepatoblastoma cell lines that can be induced to express each human PPAR. These cell lines provided evidence that human PPARs are important regulators of lipid and glycerol homeostasis and new insights about the candidate target genes of PPARs. Therefore, these cell lines are powerful tools for analysing the function of human PPARs.

\section{Methods \\ Materials}

Fenofibric acid and GW501516 were synthesized as described previously [7]. Ciglitizone was purchased from Sigma. Troglitazone was purchased from Cayman Chemical.

\section{Plasmid Constructs}

Construction of pcDNA3-hPPAR $\alpha$, pcDNA3-hPPAR $\delta$, pcDNA3-hPPAR $\gamma 1$ and pcDNA3-hPPAR 2 expression plasmids were described previously [42]. Human PPARs fragments were excised from pcDNA3-hPPAR vectors. pBI-EGFP (Clontech) was digested with PvuII, and ligated with the PPAR fragment (termed pBI-EGFP-hPPAR).

To generate human ADRP promoter-reporter plasmids, human ADRP promoter containing -2981 to +1066 bp (hADRP-4K) and the deletion promoter containing -2345 to +1066 bp (hADRP-d1) were obtained by means of PCR with the bacterial artificial chromosome (BAC) clone plasmid (BACPAC resource center at Children's Hospital Oakland Research Institute) using a forward primer 5'GGTACCTATCCCTGGTGCCAAAAAGGTTGGGGA-3'

(including a $K p n I$ site, underlined) for hADRP-4K or a forward primer 5'-GGTACCGAGAGTCTTCTGATGCAAAGTAAGAGG-3' (including a KpnI site, underlined) for hADRP-d 1 and a reverse primer 5'-AGATCTTTTTCTTCCTGGAGAAAGAAATCTGCAGAAAAGAG-3' (including a $B g l I I$ site, underlined). Each promoter was cloned into the KpnI-BglII sites of a pGL3-Basic vector (Promega). A point mutation was introduced into the ADRP promoter by PCR methodology. To generate a point-mutation construct (pGL3-hADRP-mut), a 101 bp mutant fragment was generated from forward primer (5'-GCAAAAAGAAGCTTGCTCAG-3') and reverse primer (5'GACTCTCGCCCTTaagCtTgCggAATG-3') (Mutated bases are shown as lowercase letters). Then using this $101 \mathrm{bp}$ mutant fragment for a forward primer, we amplified a 1273 bp mutant fragment using a reverse primer (5'GTGCAGGGTTATGCATTGTT-3'). The 1273 bp mutant fragment was digested with Bpu1102I and EcoT22I, and then the fragment was inserted into the Bpu1102I/ EcoT22I-digested pGL3-hADRP-4K vector.

Nucleotide sequences of these plasmids were confirmed by ABI PRISM ${ }^{\circledast} 310$ Genetic Analyzer (Applied Biosystems).

\section{Cell culture}

HepG2 cells were cultured in DMEM (Nacalai tesque) containing 10\% heat-inactivated charcoal/dextran treated foetal bovine serum (FBS) (HyClone), $100 \mathrm{IU} / \mathrm{ml}$ penicillin and $100 \mu \mathrm{g} / \mathrm{ml}$ streptomycin. The tightly tet-regulatable HepG2 cell clone (HY-Toff) which was transfected with the pTet-off vector, was isolated as previously described [22]. HY-Toff cells were co-transfected with pBIEGFP-hPPAR and pBabepuro using TransIT ${ }^{\circledR}$-LT1 Transfection Reagents (Mirus). The cells were cultured in a medium containing $600 \mu \mathrm{g} / \mathrm{ml} \mathrm{G418} \mathrm{(Nacalai} \mathrm{tesque),} 1$ $\mu \mathrm{g} / \mathrm{ml}$ puromycin (Sigma) and $1 \mu \mathrm{g} / \mathrm{ml}$ Dox (Clontech). G418- and puromycin-resistant clones were isolated. These clones were further screened for well-inducible clones by checking the expression of EGFP using fluorescence microscopy and the expression of PPAR proteins using immunoblot analysis in the absence of Dox.

\section{Quantitative Real-Time PCR}

Total RNA was isolated using an RNA preparation kit (Isogen; Nippon Gene Corp.). First strand cDNA was synthesized from $5 \mu \mathrm{g}$ of total RNA of each cell sample using the SuperScript ${ }^{\mathrm{TM}}$ First-Strand Synthesis System for RT-PCR (Invitrogen) with oligo(dT) ${ }_{12-18}$ primer. The cDNAs were then used as templates for individual PCR reactions using 
Table 2: Primers used for Real-Time PCR Analysis. Sequences of forward (For.) and reverse (Rev.) primer for each target are shown. Sequences are 5' to 3 '.

\begin{tabular}{|c|c|c|}
\hline Gene & Sequence & Size (bp) \\
\hline \multirow[t]{2}{*}{ ADRP } & For. primer : TGAGATGGCAGAGAACGGTGTG & 184 \\
\hline & Rev. primer : GGCATTGGCAACAATCTGAGT & \\
\hline \multirow[t]{2}{*}{ ANGPTL4 } & For. primer : GGGAGAGGCAGAGTGGACTATTT & 96 \\
\hline & Rev. primer : TTACTGTCCAGCCTCCATCTGA & \\
\hline \multirow[t]{2}{*}{ CLAMP/PDZKI } & For. primer : CTAAACTCTGCAGGCTGGCTAAA & 101 \\
\hline & Rev. primer : GCCCTTCTGTACCTCTTTGATGA & \\
\hline \multirow[t]{2}{*}{ HADHA } & For. primer : CAAGGGCTTCCTAGGTCGTAAAT & 155 \\
\hline & Rev. primer : GGAACTGGATGTCTTCGTCTGAT & \\
\hline \multirow[t]{2}{*}{ HMGCS2 } & For. primer : GGAACCCATATGGAGAATGTGT & 168 \\
\hline & Rev. primer : ATCGCTGCCAGCTTGCTT & \\
\hline \multirow[t]{2}{*}{ GAPDH } & For. primer : TGGGTGTGAACCATGAGAAG & 76 \\
\hline & Rev. primer : GCTAAGCAGTTGGTGGTGC & \\
\hline \multirow[t]{2}{*}{ L-FABP } & For. primer : TTGCCACCATGAGTTTCTCCG & 82 \\
\hline & Rev. primer : GGCAGACCGATTGCCTTCA & \\
\hline \multirow[t]{2}{*}{ MCAD } & For. primer : TTCCAGAGAACTGTGGAGGTCTT & 100 \\
\hline & Rev. primer : TCAATAGCAGTCTGAACCCCTGT & \\
\hline \multirow[t]{2}{*}{ PEPCK } & For. primer : TGCATGAAAGGTCGCACCA & 192 \\
\hline & Rev. primer : CACAGAATGGAGGCATTTGACA & \\
\hline \multirow[t]{2}{*}{$\operatorname{PPAR} \alpha$} & For. primer : CTATCATTTGCTGTGGAGATCG & 121 \\
\hline & Rev. primer : AAGATATCGTCCGGGTGGTT & \\
\hline \multirow[t]{2}{*}{ PPAR $\delta$} & For. primer : GTCACACAACGCTATCCGTTT & 143 \\
\hline & Rev. primer : AGGCATTGTAGATGTGCTTGG & \\
\hline \multirow[t]{2}{*}{ PPAR $\gamma$ I } & For. primer : CGTGGCCGCAGATTTGAA & 166 \\
\hline & Rev. primer : CTTCCATTACGGAGAGATCCAC & \\
\hline \multirow[t]{2}{*}{ PPAR $\gamma 2$} & For. primer : GGTGAAACTCTGGGAGATTCT & 102 \\
\hline & Rev. primer : CTCTGTGTCAACCATGGTCA & \\
\hline
\end{tabular}

specific primer sets (Table 2), which were designed by the Primer3 program written by the Whitehead Institute [43]. PCR reactions were carried out using QuantiTect ${ }^{\mathrm{TM}} \mathrm{SYBR}^{\circledR}$ Green PCR Kit (Qiagen). The quantitative PCR analysis was performed using the DNA Engine Opticon ${ }^{\mathrm{TM}}$ System (Bio-Rad Laboratories). Amplification specificity was verified by visualizing PCR products on an ethidium bromide-stained 3\% agarose gel. Glyceraldehyde-3phosphate dehydrogenase (GAPDH) was used for normalizing each expression data.

\section{Immunoblot Analysis}

Nuclear extracts were obtained as previously described [44]. Each nuclear extract $(50 \mu \mathrm{g})$ was resolved by $10 \%$ SDS-PAGE, and electroblotted to nitrocellulose membranes. Western blot analyses were carried out using antihuman PPAR $\alpha$ [H0723], PPAR $\delta$ [K7701] (Perseus Proteomics Inc.) or PPAR $\gamma$ [E-8] antibodies (Santa Cruz). The signals were visualized with the ECL detection system (Amersham Biosciences).

\section{Affymetrix Oligonucleotide Microarray Analysis}

HepG2-tet-off-hPPAR cells were cultured in the presence (Dox) or absence of Dox for 5 days. In the case of the absence of Dox, the cells were treated with PPAR ligands (100 $\mu \mathrm{M}$ fenofibric acid for PPAR $\alpha$ (Feno), $100 \mathrm{nM}$ GW501516 for PPAR $\delta$ (GW) or $10 \mu \mathrm{M}$ ciglitizone for PPAR $\gamma$ (Cig)) or vehicle (DMSO) for $24 \mathrm{~h}$. Total RNA samples were prepared from these cells using an RNA preparation kit (Isogen). Hybridization samples were prepared according to the Affymetrix protocol as previously described [7]. Briefly, $10 \mu \mathrm{g}$ total RNA was used to generate first-strand cDNA. After second-strand cRNA synthesis, biotinylated and amplified RNAs were purified using RNeasy (Qiagen) and quantitated by a spectrophotometer. Biotinylated cRNA samples were then hybridized to Affymetrix Human Genome U133A arrays. These arrays contain probe sets for $>22,000$ transcripts and EST clones. After hybridization, microarrays were washed, scanned, and analysed with the GeneChip ${ }^{\circledR}$ software Microarray Suite (MAS) Ver.5.0 (Affymetrix). The criteria for selecting genes that were induced by ligand-activated PPARs were as follows: (1) in the presence of ligand, the average difference of gene was $\geq 100$ and the gene represented as "presence"; (2) the ratio of the expression level in the presence of ligand to the expression level in the presence of Dox was greater than two; and (3) the ratio of the expression level in the presence of ligand to the expression level 
in the absence of ligand was greater than 1.5. Raw data are available at NCBI GEO, web page accession number GSE2699.

\section{Luciferase Assay}

HepG2 cells were transfected using Lipofectamine ${ }^{\mathrm{TM}} 2000$ (Invitrogen) according to the manufacturer's instructions. HepG2 cells $\left(3 \times 10^{4}\right.$ cells/well $)$ were seeded in 96-well plates $14-18 \mathrm{~h}$ before transfection. The cells were transfected with $50 \mathrm{ng}$ of human ADRP reporter plasmid, $50 \mathrm{ng}$ of phRL-TK (Promega) and either 5 ng of pcDNA3, pcDNA3-hPPAR $\alpha$, pcDNA3-hPPAR $\delta$, pcDNA3-hPPAR $\gamma 1$ or the pcDNA3-hPPAR $\gamma 2$ expression vector. Twenty-four hours following transfection, the cells were incubated with a medium containing dimethylsulfoxide (DMSO) (vehicle), $100 \mu \mathrm{M}$ fenofibric acid, $100 \mathrm{nM}$ GW501516 or $10 \mu \mathrm{M}$ ciglitizone. Following a period of $24 \mathrm{~h}$, both firefly and Renilla luciferase activities were quantified using a Dual-Luciferase ${ }^{\circledast}$ Reporter Assay System (Promega) according to manufacturer's instructions.

\section{Electrophoretic Mobility Shift Assay (EMSA)}

Human PPAR $\alpha$, human PPAR $\delta$, human PPAR $\gamma 2$ and human RXR $\alpha$ proteins were prepared using the IMPACT ${ }^{\mathrm{TM}}$ $\mathrm{CN}$ system (New England Biolabs). Human PPAR $\gamma 1$ protein was synthesized in vitro using the TNT ${ }^{\circledast}$ Quick Coupled Transcription/Translation Systems (Promega). Double-strand oligonucleotides were labelled with $[\alpha-$ $\left.{ }^{32} \mathrm{P}\right] \mathrm{dCTP}$ and a Klenow fragment and were used as probes. PPAR $\alpha$, PPAR $\delta$, PPAR $\gamma 1$, PPAR $\gamma 2$ and/or RXR $\alpha$ proteins were incubated with ${ }^{32} \mathrm{P}$-labelled probe in a total volume of $12.5 \mu \mathrm{l}$ binding buffer $(10 \mathrm{mM}$ Tris-HCl $(\mathrm{pH}$ 7.5), $5 \%$ glycerol, $1 \mathrm{mM}$ DTT, $1 \mathrm{mM}$ EDTA, $1 \mu \mathrm{g}$ poly (dI$\mathrm{dC}), 30 \mu \mathrm{g} \mathrm{BSA}$ ) at room temperature for $30 \mathrm{~min}$, followed by an incubation at $4{ }^{\circ} \mathrm{C}$ for $30 \mathrm{~min}$. Supershift assays were performed by adding antibodies $1 \mathrm{~h}$ before incubation with an oligonucleotide probe at room temperature. All monoclonal antibodies (PPAR $\alpha$ [H0723], PPAR $\delta$ [K9418], PPAR $\gamma$ [A3408A]) were obtained from Perseus Proteomics. In competition studies, the proteins were pre-incubated with 10 - or 100 -fold molar excess of unlabelled wild-type or mutant oligonucleotides. ProteinDNA complexes were resolved on a 5\% nondenaturing polyacrylamide gel in $1 \times$ TAE buffer. The loaded gel was fixed with $10 \%$ methanol and $10 \%$ acetic acid, and then the gel was dried and autoradiographed. Double-stranded oligonucleotides composed of the following sequences were used for the binding and competition assays: human ADRP PPRE wild type, 5'-GCATTTTGTAGGTGAAAGGGCGAGAGTC-3'; ADRP PPRE mutant, 5'-GCATTccGcAaGcttAAGGGCGAGAGTC-3', and rat acyl-CoA oxidase (ACO) PPRE wild type, 5'-GCGGACCAGGACAAAGGTCACGTTC-3' (Mutated bases are shown as lowercase letters).

\section{Chromatin Immunoprecipitation (ChIP) Assay}

HepG2-tet-off-hPPAR cells were cultured in the absence of Dox for 5 days. The cells were treated with PPAR ligands (100 $\mu \mathrm{M}$ fenofibric acid for PPAR $\alpha, 100 \mathrm{nM}$ GW501516 for PPAR $\delta$, or $10 \mu \mathrm{M}$ troglitazone for PPAR $\gamma$ ) for $8 \mathrm{~h}$. Cells were fixed in vivo at room temperature for $10 \mathrm{~min}$ by the addition of formaldehyde at a final concentration of $1 \%$ directly onto the cell culture media. Fixation was completed following the addition of glycine with a $0.125 \mathrm{M}$ final concentration and the incubation was continued for a further $5 \mathrm{~min}$. The cells were washed twice using ice-cold phosphate-buffered saline and collected. The cell pellets were washed with cell lysis buffer $(10 \mathrm{mM}$ Tris-HCl $(\mathrm{pH}$ 7.5), $10 \mathrm{mM} \mathrm{NaCl}, 3 \mathrm{mM} \mathrm{MgCl}_{2}, 0.5 \% \mathrm{NP}-40$, and a protease inhibitor cocktail (Sigma)) three times, and dissolved in SDS lysis buffer (10 mM Tris- $\mathrm{HCl}$ (pH 7.5), 270 $\mathrm{mM} \mathrm{NaCl}, 3 \mathrm{mM} \mathrm{MgCl}{ }_{2}, 1 \mathrm{mM} \mathrm{CaCl}_{2}, 4 \% \mathrm{NP}-40,1.3 \%$ SDS, and a protease inhibitor cocktail) and remained on ice for $10 \mathrm{~min}$. The cell lysates were sonicated to shear chromosomal DNA with an average length of $1000 \mathrm{bp}$. After centrifugation to remove insoluble materials, the chromatin solution was diluted 10-fold in an IP dilution buffer (20 mM Tris-HCl (pH 8.0), $150 \mathrm{mM} \mathrm{NaCl,} 2 \mathrm{mM}$ EDTA, $1 \%$ Triton X-100, 0.01\% SDS, and a protease inhibitor cocktail), and the diluted solution was pre-cleared with protein $G$ Sepharose beads on a rotating wheel at $4^{\circ} \mathrm{C}$ for $1 \mathrm{~h}$. Beads were removed by centrifugation and the supernatants were incubated with $2 \mu \mathrm{g}$ of antibodies to PPAR $\alpha$ (H-98, Santa Cruz), PPARס (H-74, Santa Cruz), PPAR $\gamma$ (H-100, Santa Cruz), or RXR $\alpha$ (D-20, Santa Cruz) at $4{ }^{\circ} \mathrm{C}$ overnight. For a negative control, pre-immune rabbit IgG (Santa Cruz) was incubated with the supernatant. The complexes were immunoprecipitated with protein $G$ Sepharose beads. The beads were washed once with IP dilution buffer, twice with wash buffer $1(20 \mathrm{mM}$ Tris- $\mathrm{HCl}$ (pH 8.0), $150 \mathrm{mM} \mathrm{NaCl}, 2$ mM EDTA, 1\% Triton X-100, $0.1 \%$ SDS, and a protease inhibitor cocktail), once with wash buffer 2 (20 mM Tris- $\mathrm{HCl}$ ( $\mathrm{pH} 8.0), 500 \mathrm{mM} \mathrm{NaCl}$, $2 \mathrm{mM}$ EDTA, 1\% Triton X-100, 0.1\% SDS, and a protease inhibitor cocktail), once with wash buffer 3 (10 mM Tris$\mathrm{HCl}$ (pH 8.0), 1 mM EDTA, $0.25 \mathrm{M} \mathrm{LiCl,} \mathrm{1 \%} \mathrm{NP-40,} \mathrm{1 \%}$ deoxycholate), and twice with TE buffer. Immune complexes were eluted from the beads in the elution buffer (25 mM Tris-HCl (pH 7.5), 5 mM EDTA, 0.5\% SDS, 10 $\mathrm{mM}$ DTT) for $15 \mathrm{~min}$. The proteins were removed from DNA by digesting with $1.5 \mathrm{mg} / \mathrm{ml}$ pronase at $42^{\circ} \mathrm{C}$ for 2 h. The crosslink was reversed by adding $5 \mathrm{M} \mathrm{NaCl}$ to a final concentration of $200 \mathrm{mM}$ followed by incubation at $65^{\circ} \mathrm{C}$ for $6 \mathrm{~h}$. The sample DNAs were then extracted with phenol-chloroform-isoamyl alcohol (25:24:1), precipitated with ethanol in the presence of glycogen, and resuspended in TE buffer. Similarly purified DNA fragments from the chromatin extracts (input) were used as a control for PCR reactions. Precipitated DNAs were analysed by PCR of 32 cycles using primers 5'-GCAAAAAGAAGCTT- 
GCTCAG-3' and 5'-TGTTGCCATCTTCAGTGTTT-3' that flanked the PPRE of the ADRP promoter or primers $5^{\prime}-$ ATGGTTGCCACTGGGGATCT-3' and 5'TGCCAAAGCCTAGGGGAAGA-3' that are located about 6 -kb upstream of the GAPDH promoter (negative control). PCR products were separated on a $2 \%$ agarose gel and stained with ethidium bromide.

\section{List of Abbreviations}

ACO, acyl-CoA oxidase; ADRP, adipose differentiationrelated protein; ANGPTL4, angiopoietin-like protein 4; CLAMP/PDZK1, C-terminal linking and modulating protein/PDZ domain containing 1; DMSO, dimethylsulfoxide; Dox, doxycycline; GAPDH, glyceraldehyde-3phosphate dehydrogenase; HADHA, hydroxyacyl-Coenzyme A dehydrogenase/3-ketoacyl-Coenzyme A thiolase/ enoyl-Coenzyme A hydratase (trifunctional protein), $\alpha$ subunit; HDL, high density lipoprotein; HMGCS2, 3hydroxy-3-methylglutaryl-Coenzyme A synthase 2 (mitochondrial); L-FABP, fatty acid binding protein 1, liver; MCAD, acyl-Coenzyme A dehydrogenase, C-4 to C-12 straight chain; PEPCK, phosphoenolpyruvate carboxykinase 1; PPAR, peroxisome proliferator-activated receptor; PPRE, peroxisome proliferator responsive element; RXR, retinoid $\mathrm{X}$ receptor; Tet, tetracycline.

\section{Competing interests}

The author(s) declare that they have no competing interests.

\section{Authors' contributions}

K. Tachibana carried out all the experiments and prepared the manuscript. Y. Kobayashi performed the reporter gene assays. T. Tanaka participated in designing the experiments. Y. Kobayashi and A. Sugiyama generated the human ADRP promoter-reporter plasmids. Y. Kobayashi, M. Tagami, T. Katayama, C. Ueda, D. Yamasaki, K. Ishimoto, and M. Sumitomo assisted with cell culture and the establishment of the stable cell lines. Y. Kobayashi, M. Tagami, T. Katayama, C. Ueda, and Y. Uchiyama performed the immunoblot analyses. T. Kohro assisted with the analysis of the microarray data. J. Sakai, T. Hamakubo, T. Kodama, and T. Doi developed the idea for the study, and participated in its design and coordination. All authors read and approved the final manuscript.

\section{Additional material}

\section{Additional File 1}

Changes in mRNA expression levels in HepG2-tet-off-hPPAR cell lines by ligands. Microarray analyses were performed on HepG2-tet-offhPPAR cells; the cells were cultured in the presence (Dox) or absence of Dox for 5 days. In the absence of Dox, the cells were treated with PPAR ligands (100 $\mu \mathrm{M}$ fenofibric acid for PPAR $\alpha$ (Feno), $100 \mathrm{nM} \mathrm{GW501516}$ for PPAR $\delta(G W)$ or $10 \mu \mathrm{M}$ ciglitizone for PPAR $\gamma(\mathrm{Cig}))$ or vehicle (DMSO) for $24 \mathrm{~h}$. Gene expression profiles were compared between DMSO and Dox (DMSO versus Dox), ligands and Dox (Feno versus Dox, GW versus Dox, and Cig versus Dox were indicated in the case of PPAR $\alpha, P P A R \delta$ and PPAR $\gamma$, respectively) or ligands and DMSO (Feno versus DMSO, GW versus DMSO, and Cig versus DMSO were indicated in the case of PPAR $\alpha, P P A R \delta$ and PPAR $\gamma$, respectively). Average differences expressed the intensities of the mRNA levels in HepG2-tet-offhPPARs cell lines. Samples were analysed using GeneChip ${ }^{\circledast}$ software Microarray Suite (MAS) Ver.5.0 (Affymetrix).

Click here for file

[http://www.biomedcentral.com/content/supplementary/14781336-3-3-S1.xls]

\section{Acknowledgements}

We thank Dr. Ying Huang and Dr. Yutaka Midorikawa for their help in establishing the stable cell lines, and Ms Akashi Izumi for the excellent technique used in the DNA microarray analysis experiments.

\section{References}

I. Mangelsdorf DJ, Thummel C, Beato M, Herrlich P, Schutz G, Umesono K, Blumberg B, Kastner P, Mark M, Chambon P, Evans RM: The nuclear receptor superfamily: the second decade. Cell 1995, 83(6):835-839.

2. Desvergne B, Wahli W: Peroxisome proliferator-activated receptors: nuclear control of metabolism. Endocr Rev 1999, 20(5):649-688.

3. Willson TM, Brown PJ, Sternbach DD, Henke BR: The PPARs: from orphan receptors to drug discovery. J Med Chem 2000, 43(4):527-550.

4. Mandard S, Muller M, Kersten S: Peroxisome proliferator-activated receptor alpha target genes. Cell Mol Life Sci 2004, 6 I (4):393-416.

5. Corton JC, Lapinskas PJ, Gonzalez FJ: Central role of PPARalpha in the mechanism of action of hepatocarcinogenic peroxisome proliferators. Mutat Res 2000, 448(2): |39-I5I.

6. Cheung C, Akiyama TE, Ward JM, Nicol CJ, Feigenbaum L, Vinson C, Gonzalez FJ: Diminished hepatocellular proliferation in mice humanized for the nuclear receptor peroxisome proliferator-activated receptor alpha. Cancer Res 2004, 64( I I ):3849-3854.

7. Tanaka T, Yamamoto J, Iwasaki S, Asaba H, Hamura H, lkeda $Y$, Watanabe M, Magoori K, loka RX, Tachibana K, Watanabe Y, Uchiyama Y, Sumi K, Iguchi H, Ito S, Doi T, Hamakubo T, Naito M, Auwerx J, Yanagisawa M, Kodama T, Sakai J: Activation of peroxisome proliferator-activated receptor delta induces fatty acid betaoxidation in skeletal muscle and attenuates metabolic syndrome. Proc Natl Acad Sci U S A 2003, I 00(26): I 5924- I 5929.

8. Dressel U, Allen TL, Pippal JB, Rohde PR, Lau P, Muscat GE: The peroxisome proliferator-activated receptor beta/delta agonist, GW50I5 I6, regulates the expression of genes involved in lipid catabolism and energy uncoupling in skeletal muscle cells. Mol Endocrinol 2003, I 7( I 2):2477-2493.

9. Wang YX, Lee CH, Tiep S, Yu RT, Ham J, Kang H, Evans RM: Peroxisome-proliferator-activated receptor delta activates fat metabolism to prevent obesity. Cell 2003, I I3(2): I59-170.

10. Tan NS, Michalik L, Noy N, Yasmin R, Pacot C, Heim M, Fluhmann B, Desvergne $B$, Wahli W: Critical roles of PPAR beta/delta in 
keratinocyte response to inflammation. Genes Dev 200I, I 5(24):3263-3277.

II. Chawla A, Lee CH, Barak Y, He W, Rosenfeld J, Liao D, Han J, Kang $\mathrm{H}$, Evans RM: PPARdelta is a very low-density lipoprotein sensor in macrophages. Proc Natl Acad Sci U S A 2003, I00(3): I 268-1273.

12. Tontonoz P, Hu E, Graves RA, Budavari Al, Spiegelman BM: mPPAR gamma 2: tissue-specific regulator of an adipocyte enhancer. Genes Dev 1994, 8( I 0): I 224-I 234.

13. Tontonoz P, Hu E, Spiegelman BM: Stimulation of adipogenesis in fibroblasts by PPAR gamma 2, a lipid-activated transcription factor. Cell 1994, 79(7): | |47-|| 56.

14. Vidal-Puig A, Jimenez-Linan M, Lowell BB, Hamann A, Hu E, Spiegelman $B$, Flier JS, Moller DE: Regulation of PPAR gamma gene expression by nutrition and obesity in rodents. J Clin Invest 1996, 97(II):2553-256I.

15. Chao L, Marcus-Samuels B, Mason MM, Moitra J, Vinson C, Arioglu E, Gavrilova O, Reitman ML: Adipose tissue is required for the antidiabetic, but not for the hypolipidemic, effect of thiazolidinediones. J Clin Invest 2000, I06( I0): | 22I-I 228

16. Memon RA, Tecott LH, Nonogaki K, Beigneux A, Moser AH, Grunfeld $C$, Feingold KR: Up-regulation of peroxisome proliferatoractivated receptors (PPAR-alpha) and PPAR-gamma messenger ribonucleic acid expression in the liver in murine obesity: troglitazone induces expression of PPAR-gammaresponsive adipose tissue-specific genes in the liver of obese diabetic mice. Endocrinology 2000, I 4 I (II):402I-403I.

17. Bedoucha M, Atzpodien E, Boelsterli UA: Diabetic KKAy mice exhibit increased hepatic PPARgammal gene expression and develop hepatic steatosis upon chronic treatment with antidiabetic thiazolidinediones. J Hepatol 200I, 35(I): 17-23.

18. Kliewer SA, Umesono K, Noonan DJ, Heyman RA, Evans RM: Convergence of 9-cis retinoic acid and peroxisome proliferator signalling pathways through heterodimer formation of their receptors. Nature 1992, 358(6389):77/-774.

19. Hsu MH, Palmer CN, Song W, Griffin KJ, Johnson EF: A carboxylterminal extension of the zinc finger domain contributes to the specificity and polarity of peroxisome proliferator-activated receptor DNA binding. I Biol Chem 1998, 273(43):27988-27997.

20. Gervois P, Chopin-Delannoy S, Fadel A, Dubois G, Kosykh V, Fruchart JC, Najib J, Laudet V, Staels B: Fibrates increase human REV-ERBalpha expression in liver via a novel peroxisome proliferator-activated receptor response element. Mol Endocrinol 1999, 13(3):400-409.

21. Schoonjans K, Staels B, Auwerx J: Role of the peroxisome proliferator-activated receptor (PPAR) in mediating the effects of fibrates and fatty acids on gene expression. J Lipid Res 1996, 37(5):907-925.

22. Huang $Y$, Uchiyama $Y$, Fujimura $T$, Kanamori H, Doi T, Takamizawa A, Hamakubo T, Kodama T: A human hepatoma cell line expressing hepatitis c virus nonstructural proteins tightly regulated by tetracycline. Biochem Biophys Res Commun 200I, 28I(3):732-740

23. Gavrilova O, Haluzik M, Matsusue K, Cutson JJ, Johnson L, Dietz KR, Nicol C], Vinson C, Gonzalez F], Reitman ML: Liver peroxisome proliferator-activated receptor gamma contributes to hepatic steatosis, triglyceride clearance, and regulation of body fat mass. I Biol Chem 2003, 278(36):34268-34276.

24. Kersten S, Seydoux J, Peters JM, Gonzalez FJ, Desvergne B, Wahli W: Peroxisome proliferator-activated receptor alpha mediates the adaptive response to fasting. I Clin Invest 1999, I03(II): I 1489-1498.

25. Leone TC, Weinheimer CJ, Kelly DP: A critical role for the peroxisome proliferator-activated receptor alpha (PPARalpha) in the cellular fasting response: the PPARalpha-null mouse as a model of fatty acid oxidation disorders. Proc Natl Acad $\mathrm{SC}$ U S A 1999, 96(13):7473-7478.

26. Patsouris D, Mandard S, Voshol PJ, Escher P, Tan NS, Havekes LM, Koenig W, Marz W, Tafuri S, Wahli W, Muller M, Kersten S: PPARalpha governs glycerol metabolism. J Clin Invest 2004, I I 4(I):94-103.

27. Way JM, Harrington WW, Brown KK, Gottschalk WK, Sundseth SS, Mansfield TA, Ramachandran RK, Willson TM, Kliewer SA: Comprehensive messenger ribonucleic acid profiling reveals that peroxisome proliferator-activated receptor gamma activa- tion has coordinate effects on gene expression in multiple insulin-sensitive tissues. Endocrinology 200I, I 42(3): I 269-I 277.

28. Bernal-Mizrachi C, Weng S, Feng C, Finck BN, Knutsen RH, Leone TC, Coleman T, Mecham RP, Kelly DP, Semenkovich CF: Dexamethasone induction of hypertension and diabetes is PPARalpha dependent in LDL receptor-null mice. Nat Med 2003, 9(8): 1069-1075.

29. Kocher O, Comella N, Tognazzi K, Brown LF: Identification and partial characterization of PDZKI: a novel protein containing PDZ interaction domains. Lab Invest 1998, 78(I): I I7- 125.

30. Ikemoto M, Arai H, Feng D, Tanaka K, Aoki J, Dohmae N, Takio K, Adachi $\mathrm{H}$, Tsujimoto $M$, Inoue $\mathrm{K}$ : Identification of a PDZ-domaincontaining protein that interacts with the scavenger receptor class B type I. Proc Natl Acad Sci U S A 2000, 97( ( 2):6538-6543.

3I. Silver DL: A carboxyl-terminal PDZ-interacting domain of scavenger receptor $B$, type $I$ is essential for cell surface expression in liver. J Biol Chem 2002, 277(37):34042-34047.

32. Acton S, Rigotti A, Landschulz KT, Xu S, Hobbs HH, Krieger M: Identification of scavenger receptor SR-BI as a high density lipoprotein receptor. Science 1996, 27 I(5248):5I8-520.

33. Murao K, Terpstra V, Green SR, Kondratenko N, Steinberg D, Quehenberger O: Characterization of CLA-I, a human homologue of rodent scavenger receptor $\mathrm{BI}$, as a receptor for high density lipoprotein and apoptotic thymocytes. J Biol Chem 1997, 272(28): 1755|-17557.

34. Margeli A, Kouraklis G, Theocharis S: Peroxisome proliferator activated receptor-gamma (PPAR-gamma) ligands and angiogenesis. Angiogenesis 2003, 6(3):165-169.

35. Shi Y, Hon M, Evans RM: The peroxisome proliferator-activated receptor delta, an integrator of transcriptional repression and nuclear receptor signaling. Proc Natl Acad Sci U S A 2002, 99(5):26|3-26|8

36. Krogsdam AM, Nielsen CA, Neve S, Holst D, Helledie T, Thomsen B, Bendixen C, Mandrup S, Kristiansen K: Nuclear receptor corepressor-dependent repression of peroxisome-proliferatoractivated receptor delta-mediated transactivation. Biochem J 2002, 363(Pt I): I57-165.

37. Brasaemle DL, Barber T, Wolins NE, Serrero G, Blanchette-Mackie E], Londos C: Adipose differentiation-related protein is an ubiquitously expressed lipid storage droplet-associated protein. J Lipid Res 1997, 38(I I):2249-2263.

38. Targett-Adams P, McElwee MJ, Ehrenborg E, Gustafsson MC, Palmer $\mathrm{CN}$, McLauchlan J: A PPAR response element regulates transcription of the gene for human adipose differentiationrelated protein. Biochim Biophys Acta 2005, I 728(I-2):95-104.

39. Cheng L, Ding G, Qin Q, Huang Y, Lewis W, He N, Evans RM, Schneider MD, Brako FA, Xiao Y, Chen YE, Yang Q: Cardiomyocyterestricted peroxisome proliferator-activated receptor-delta deletion perturbs myocardial fatty acid oxidation and leads to cardiomyopathy. Nat Med 2004, I ( I I ): I245-I250.

40. Oliver WRJ, Shenk JL, Snaith MR, Russell CS, Plunket KD, Bodkin NL, Lewis MC, Winegar DA, Sznaidman ML, Lambert MH, Xu HE, Sternbach DD, Kliewer SA, Hansen BC, Willson TM: A selective peroxisome proliferator-activated receptor delta agonist promotes reverse cholesterol transport. Proc Natl Acad Sci U S A 200I, 98(9):5306-53II.

4I. Giddings SJ, Clarke SE, Gibson GG: CYP4AI gene transfection studies and the peroxisome proliferator-activated receptor: development of a high-throughput assay to detect peroxisome proliferators. Eur J Drug Metab Pharmacokinet 1997, 22(4):3|5-3| 9 .

42. Tanaka T, Takeno T, Watanabe $\mathrm{Y}$, Uchiyama $\mathrm{Y}$, Murakami T, Yamashita H, Suzuki A, Aoi R, Iwanari H, Jiang SY, Naito M, Tachibana K, Doi T, Shulman Al, Mangelsdorf DJ, Reiter R, Auwerx J, Hamakubo T, Kodama $\mathrm{T}$ : The generation of monoclonal antibodies against human peroxisome proliferator-activated receptors (PPARs). J Atheroscler Thromb 2002, 9(5):233-242.

43. Rozen S, Skaletsky H: Primer3 on the WWW for general users and for biologist programmers. Methods Mol Biol 2000 , 132:365-386.

44. Minami T, Tachibana K, Imanishi T, Doi T: Both Ets-I and GATAI are essential for positive regulation of platelet factor 4 gene expression. Eur J Biochem I998, 258(2):879-889. 